ARTICLE

\title{
Bulk tungsten-substituted vanadium oxide for low- temperature NOx removal in the presence of water
}

\author{
Yusuke Inomata (1) ', Hiroe Kubota ${ }^{2}$, Shinichi Hata ${ }^{3}$, Eiji Kiyonaga ${ }^{4}$, Keiichiro Morita ${ }^{4}$, Kazuhiro Yoshida ${ }^{4}$, \\ Norihito Sakaguchi (10 5 , Takashi Toyao (1) ${ }^{2}$, Ken-ichi Shimizu ${ }^{2,8}$, Satoshi Ishikawa ${ }^{6}$, Wataru Ueda ${ }^{6}$,

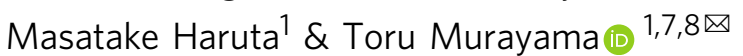

$\mathrm{NH}_{3}$-SCR (selective catalytic reduction) is important process for removal of NOx. However, water vapor included in exhaust gases critically inhibits the reaction in a low temperature range. Here, we report bulk $\mathrm{W}$-substituted vanadium oxide catalysts for $\mathrm{NH}_{3}-\mathrm{SCR}$ at a low temperature $\left(100-150^{\circ} \mathrm{C}\right)$ and in the presence of water $(20 \mathrm{vol} \%)$. The $3.5 \mathrm{~mol} \% \mathrm{~W}$ substituted vanadium oxide shows $>99 \%$ (dry) and $\sim 93 \%$ (wet, $5-20$ vol\% water) NO conversion at $150{ }^{\circ} \mathrm{C}\left(250 \mathrm{ppm} \mathrm{NO}, 250 \mathrm{ppm} \mathrm{NH}, 4 \% \mathrm{O}_{2}, \mathrm{SV}=40000 \mathrm{~mL} \mathrm{~h}^{-1} \mathrm{~g}_{\text {cat }}{ }^{-1}\right)$. Lewis acid sites of $\mathrm{W}$-substituted vanadium oxide are converted to Brønsted acid sites under a wet condition while the distribution of Brønsted and Lewis acid sites does not change without tungsten. $\mathrm{NH}_{4}{ }^{+}$species adsorbed on Brønsted acid sites react with $\mathrm{NO}$ accompanied by the reduction of $\mathrm{V}^{5+}$ sites at $150^{\circ} \mathrm{C}$. The high redox ability and reactivity of Brønsted acid sites are observed for bulk $\mathrm{W}$-substituted vanadium oxide at a low temperature in the presence of water, and thus the catalytic cycle is less affected by water vapor.

\footnotetext{
${ }^{1}$ Research Center for Gold Chemistry, Graduate School of Urban Environmental Sciences, Tokyo Metropolitan University Hachioji, Tokyo 192-0397, Japan ${ }^{2}$ Institute for Catalysis, Hokkaido University, Sapporo, Hokkaido 001-0021, Japan. ${ }^{3}$ Department of Applied Chemistry, Faculty of Engineering, Sanyo-Onoda City University, Sanyo-Onoda, Yamaguchi 756-0884, Japan. ${ }^{4}$ Energia Economic and Technical Research Institute, The Chugoku Electric Power Company, Incorporated, Higashihiroshima, Hiroshima 739-0046, Japan. ${ }^{5}$ Laboratory of Integrated Function Materials, Center for Advanced Research of Energy and Materials, Faculty of Engineering, Hokkaido University, Sapporo, Hokkaido 060-8628, Japan. ${ }^{6}$ Department of Material and Life Chemistry, Faculty of Engineering, Kanagawa University, Yokohama, Kanagawa 221-8686, Japan. ${ }^{7}$ Yantai Key Laboratory of Gold Catalysis and Engineering, Shandong Applied Research Center of Gold Nanotechnology (Au-SDARC) School of Chemistry and Chemical Engineering, Yantai University, Yantai 264005, China. ${ }^{8}$ These authors jointly supervised this work: Ken-ichi Shimizu, Toru Murayama. ${ }^{凶}$ email: murayama@tmu.ac.jp
} 
E mission control of $\mathrm{NO}_{x}\left(\mathrm{NO}\right.$ and $\left.\mathrm{NO}_{2}\right)$ is an important task for an industrial chemical process that relies on thermal energy produced by the combustion of fossil fuels. For stationary de $\mathrm{NO}_{x}$ systems such as those in coal-fired power plants and waste treatment plants, selective catalytic reduction (SCR) has been used with ammonia as a reducing reagent to convert harmful $\mathrm{NO}_{x}$ to harmless $\mathrm{N}_{2}$ and $\mathrm{H}_{2} \mathrm{O}^{1-3}$ :

$$
4 \mathrm{NO}+4 \mathrm{NH}_{3}+\mathrm{O}_{2} \rightarrow 4 \mathrm{~N}_{2}+6 \mathrm{H}_{2} \mathrm{O} \text {. }
$$

Although the stationary deNO ${ }_{x}$ systems have been successfully established, a conventional catalyst needs a high temperature $\left(>300^{\circ} \mathrm{C}\right.$ ) for $\mathrm{NH}_{3}$-SCR to proceed ${ }^{3,4}$. In most cases, deNO ${ }_{x}$ catalysts are placed just after the boiler system for a high reaction temperature ${ }^{4}$. Consequently, deNO $\mathrm{N}_{x}$ catalysts are deactivated by ash and sulfate generated from the reaction of ammonia and $\mathrm{SO}_{2}$ because the catalysts are exposed to the gas before passing through the dust collection and $\mathrm{deSO}_{x}$ system. $\mathrm{DeNO}_{x}$ catalysts can be moved to the latter part of the system to avoid the deactivation of the $\mathrm{deNO}_{x}$ catalyst works at a low temperature $\left(<150^{\circ} \mathrm{C}\right)$ since the downstream gas is usually cooled down to $100-150^{\circ} \mathrm{C}$.

Vanadium (V) oxide-based catalysts $\left(\mathrm{V}_{2} \mathrm{O}_{5} / \mathrm{TiO}_{2}, \mathrm{~V}_{2} \mathrm{O}_{5}-\mathrm{WO}_{3} /\right.$ $\mathrm{TiO}_{2}$ ) have been used as industrial catalysts for stationary boiler systems because they show high $\mathrm{N}_{2}$ selectivity, good thermal stability, and low $\mathrm{SO}_{2}$ oxidation activity to $\mathrm{SO}_{3}^{2}$. However, their high working temperature limits the latitude of the $\operatorname{deNO}_{x}$ process. Therefore, many studies have been carried out to develop low-temperature SCR catalysts such as metal oxide-based materials $(\mathrm{V}, \mathrm{Mn}, \mathrm{Cr}, \mathrm{Cu}, \mathrm{W}, \mathrm{Ce} \text {, and } \mathrm{Fe})^{1,5-10}$ and ion-exchanged zeolite (Cu-ZSM-5, Fe-ZSM-5, Cu-CHA, and Cu-SSZ-13)1,11-17.

We previously showed that vanadium oxide with a bulk crystal structure works as an $\mathrm{NH}_{3}$-SCR catalyst at a low temperature $\left(<150{ }^{\circ} \mathrm{C}\right)$ with high $\mathrm{N}_{2}$ selectivity and less $\mathrm{SO}_{2}$ oxidation activity in contrast to the supported vanadia species ${ }^{18,19}$. Recent studies provided an insight into the effect of the coordination environment, atomic configuration, and vanadium surface density of the catalyst on SCR activity ${ }^{20-22}$. It was proposed in previous reports that supported vanadia catalysts are composed of $\mathrm{VO}_{4}$ units with $\mathrm{O}$-exposed moieties ${ }^{2,23}$. On the other hand, bulk $\mathrm{V}_{2} \mathrm{O}_{5}$ has a metal (V)-exposed part in addition to the O-exposed part ${ }^{24}$, and it might show a different catalytic property from that of a supported vanadia catalyst because of their different redox properties, bond strengths, and coordination environments ${ }^{23,25}$. Bulk crystal of $\mathrm{V}_{2} \mathrm{O}_{5}$ is composed of a two-dimensional sheet structure with $\mathrm{VO}_{5}$ units that are connected by a weak van der Waals force $\mathrm{e}^{24,26-29}$. Consequently, the morphology of $\mathrm{V}_{2} \mathrm{O}_{5}$ is thermally reconstructed because of its weak interaction in the crystal structure. According to previous studies, the poor stability of $\mathrm{V}_{2} \mathrm{O}_{5}$ can be overcome by doping another metal with a three-dimensional coordination environment ${ }^{30-32}$. Bulk tungsten oxide $\left(\mathrm{WO}_{3}\right)$ is composed of $\mathrm{WO}_{6}$ units that are three-dimensionally connected ${ }^{33-35}$. Furthermore, $\mathrm{WO}_{3}$ is known as a promoter for supported vanadia catalysts that enhance the reactivity of vanadia sites ${ }^{36}$. Therefore, the incorporation of tungsten sites into bulk $\mathrm{V}_{2} \mathrm{O}_{5}$ would facilitate not only the $\mathrm{NH}_{3}$-SCR activity but also the structural stability of bulk vanadium oxide-based catalysts.

The negative effect of water, which is intrinsically included in the exhaust gas $(10-30 \mathrm{vol} \%)^{2}$, is critical for low-temperature $\mathrm{NH}_{3}$-SCR, while the effect would be much less in a hightemperature range. The effect of water is thought to be inhibition of the adsorption of the reactant ${ }^{37-43}$ and/or the reaction between $\mathrm{NO}$ and adsorbed $\mathrm{NH}_{3}{ }^{44-46}$. The water adsorption behavior was studied for a $\mathrm{V}_{2} \mathrm{O}_{5}-\mathrm{WO}_{3}$ solid solution system and $\mathrm{V}_{2} \mathrm{O}_{5}$ without tungsten ${ }^{47-49}$. Broclawik et al. ${ }^{48}$ theoretically suggested that dissociative adsorption of water occurs on adjacent V-O-W sites, leading to an increase in the concentration of Brønsted acid sites.
On the other hand, water merely adsorbs in the case of $\mathrm{V}_{2} \mathrm{O}_{5}$ without tungsten, and a Brønsted acid site is not newly created. Thus, $\mathrm{NH}_{3}$-SCR would efficiently proceed with a vanadium-tungsten complex oxide even in the presence of water vapor owing to the large population of protonic Brønsted acid sites.

The reaction mechanisms of $\mathrm{NH}_{3}$-SCR have been widely investigated for a supported vanadium-based oxide catalyst under a dry gas condition using in situ and operando spectroscopic techniques (infrared (IR), ultraviolet-visible (UV-Vis), Raman $)^{20,36,38,46,50-54}$. The current consensus is that both Lewis acid and Brønsted acid sites participate in the reaction mechanism. The reaction mechanism should be investigated in the presence of water as well as under dry conditions in order to understand catalytic activity in the actual atmosphere. Although Topsøe et al. ${ }^{45}$ and Song et al. ${ }^{55}$ investigated the reaction mechanism of 3-6 $\mathrm{wt} \% \mathrm{~V}_{2} \mathrm{O}_{5} / \mathrm{TiO}_{2}$ under a $1.7-3.0 \mathrm{vol} \%$ water atmosphere at $250-300{ }^{\circ} \mathrm{C}$, the reaction mechanism of the vanadium- $\mathrm{WO}_{3}$ system has not been investigated under wet conditions, especially in a low-temperature range. An insight into the reaction mechanism under wet conditions would provide a milestone for designing the active site of a low-temperature $\mathrm{NH}_{3}-$ SCR catalyst under actual conditions.

Herein, we report a bulk tungsten-substituted vanadium oxide catalyst for low-temperature $\mathrm{NH}_{3}$-SCR $\left(<150^{\circ} \mathrm{C}\right)$ under a wet atmosphere. The structural features of bulk tungsten-substituted vanadium oxide are studied. We examine the effect of tungsten substitution on water tolerance to $\mathrm{NH}_{3}$-SCR activity and catalytic stability. The reaction mechanism is investigated by operando spectroscopies under dry and wet conditions to elucidate the role of vanadium and tungsten sites in the catalytic cycle. Finally, we compare the difference between bulk tungsten-substituted vanadium oxide catalyst and a current titania-supported vanadia catalyst.

\section{Results}

Synthesis of tungsten-substituted vanadium oxide. Tungstensubstituted vanadium oxide was synthesized by the oxalate method using ammonia metavanadate, ammonia metatungstate, and oxalic acid. Water-insoluble ammonia metavanadate was converted to soluble vanadium oxalate in aqueous media, and ammonia metatungstate was then added to the aqueous solution followed by evaporation. The resulting precursor powder was then calcined in air. The synthesized $x$ mol\% tungsten-substituted vanadium oxides were denoted as $x \mathrm{~W}-\mathrm{V}(x=0,1,3.5,7,10,15$, and 40 ). The precursor powder of the $3.5 \mathrm{~W}-\mathrm{V}$ sample showed a strong exothermic peak assigned to its decomposition at around $297^{\circ} \mathrm{C}$ from thermogravimetry/differential thermal analysis measurement (Supplementary Fig. 2). Thus, we calcined the catalyst twice at $300{ }^{\circ} \mathrm{C}$ for $4 \mathrm{~h}$ each time to obtain $\mathrm{V}_{2} \mathrm{O}_{5}$-based catalysts with large surface areas. The specific surface areas of the $x \mathrm{~W}-\mathrm{V}(x=0-40)$ catalysts were measured to be $32-41 \mathrm{~m}^{2} \mathrm{~g}^{-1}$ (Supplementary Table 2), which are almost in the same range and comparably large.

Characterization of tungsten-substituted vanadium oxide. Atomic-resolution high-angle annular dark-field imaging-scanning transmission electron microscopy (HAADF-STEM) images were measured to directly determine the incorporation of tungsten into vanadium oxide. The image of $0 \mathrm{~W}-\mathrm{V}\left(\mathrm{V}_{2} \mathrm{O}_{5}\right.$ without tungsten) showed a lattice fringe based on the (101) plane (Fig. 1a). No bright spots of tungsten atoms were observed for $0 \mathrm{~W}-\mathrm{V}$. On the other hand, we confirmed atomic bright spots on the vanadium oxide lattice for $3.5 \mathrm{~W}-\mathrm{V}$ (Fig. 1b), indicating that tungsten atoms were atomically dispersed. An enlarged view of 


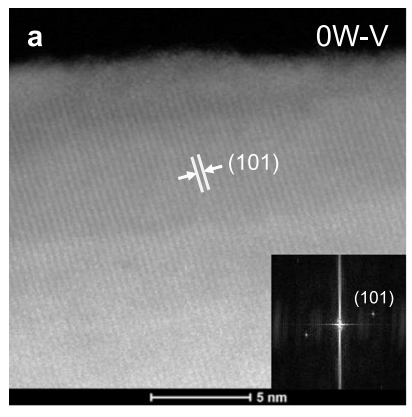

d
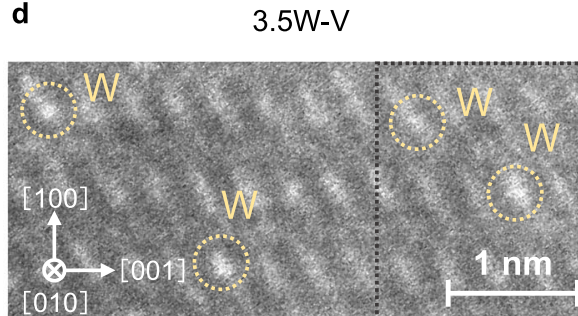

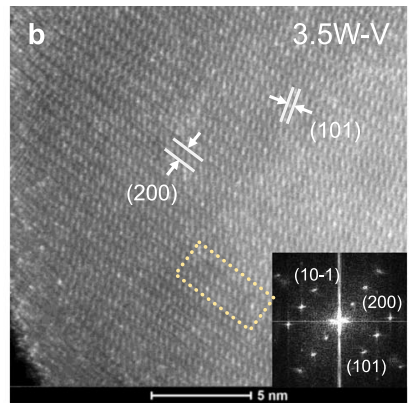

e

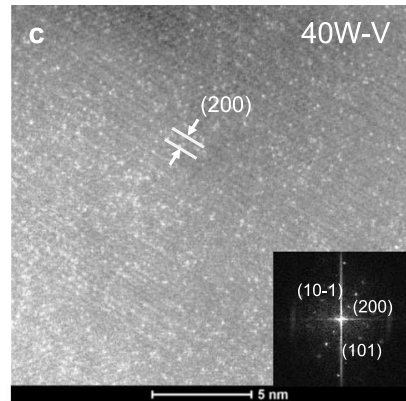

(101)

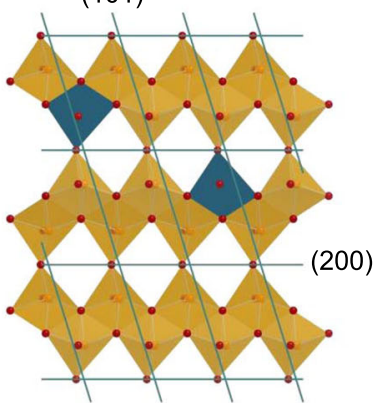

Fig. 1 Direct observation of tungsten substitution. HAADF-STEM images of a 0 , b 3.5 , and c 40 mol\% W-substituted vanadium oxide ( $0,3.5$, and 40W-V). Insets: corresponding FFT images. d Enlarged view of the yellow region in (b). e Crystal structure of W-substituted vanadium oxide. Orange polyhedra: vanadium units; blue polyhedra: tungsten units.

the HAADF-STEM image for 3.5W-V (Fig. 1d) showed that lattice vanadium atoms were partially substituted by tungsten atoms (Fig. 1e). Aggregated tungsten sites were observed on the surfaces of catalysts when $7 \mathrm{~mol} \%$ tungsten was added to vanadium oxide (7W-V; Supplementary Fig. 3). Adjacent and aggregated tungsten moieties were more clearly observed when $40 \mathrm{~mol} \%$ tungsten was added to vanadium oxide $(40 \mathrm{~W}-\mathrm{V}$; Fig. 1c), indicating that a $\mathrm{WO}_{3}$ phase partially forms with an increase in the amount of tungsten. Thus, $0,3.5$, and $40 \mathrm{~W}-\mathrm{V}$ can be regarded as catalysts without tungsten, with a moderate amount of tungsten and with an excess amount of tungsten, respectively.

The crystal structures of $x \mathrm{~W}-\mathrm{V}$ were confirmed from $\mathrm{X}$-ray powder diffraction (XRD) measurements to determine the effect of tungsten doping (Fig. 2a). For 0,1 , and $3.5 \mathrm{~W}-\mathrm{V}$, all of the diffraction peaks were assigned as vanadium oxide phase (Fig. $2 \mathrm{a}$, b), and no $\mathrm{WO}_{3}$ crystalline phase was confirmed. Given that the HAADF-STEM images showed tungsten dispersed atomically, the XRD patterns suggested that tungsten atoms were atomically incorporated into the vanadium oxide lattice and a $\mathrm{W}-\mathrm{V}$ oxide solid solution was formed. We confirmed broad XRD peaks of $\mathrm{WO}_{3}$ (Fig. $2 \mathrm{a}, \mathrm{c}$ ) at $2 \theta=23^{\circ}$ for $7,10,15$, and $40 \mathrm{~W}-\mathrm{V}$ in addition to the XRD patterns of vanadium oxide. These results indicate that tiny $\mathrm{WO}_{3}$ crystalline particles form when the tungsten content is higher than $7 \mathrm{~mol} \%$ as shown by HAADF-STEM images. The peak positions of (010) reflection at around $2 \theta=$ $20.2^{\circ}$ slightly increased with an increase in the amount of tungsten (Fig. 2a, inset), indicating that the lattice spacing decreased along the $b$-axis. The lattice parameters were calculated by Rietveld analysis. The lattice parameters of the $b$-axis decreased with an increase in the amount of tungsten (Supplementary Fig. 4b). These results show that $\mathrm{WO}_{6}$ units connect the vanadium oxide layers by bond formation (e.g., $\mathrm{V}=$ $\mathrm{O} \rightarrow \mathrm{V}-\mathrm{O}-\mathrm{W}$ ). The lattice parameters along the $a$-axis and $c$-axis were expanded because of the incorporation of tungsten atoms with a larger ionic radius (Supplementary Fig. 4a, c).

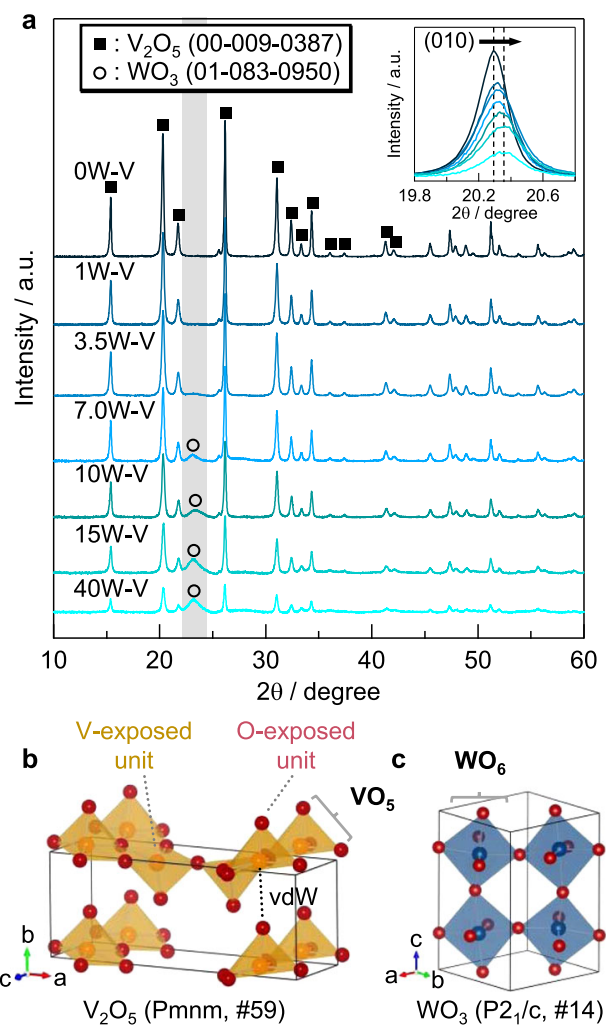

Fig. 2 Crystal structures of $\mathbf{W}$-substituted vanadium oxide catalysts. a XRD patterns of $\mathrm{W}$-substituted vanadium oxide catalysts. Inset: enlarged view of peaks corresponding to (010) reflection. (All of the peaks $2 \theta>40^{\circ}$ were also assigned to $\mathrm{V}_{2} \mathrm{O}_{5}$.) Crystal structures of $\mathbf{b} \mathrm{V}_{2} \mathrm{O}_{5}$ and $\mathbf{c} \mathrm{WO}_{3}$. Orange polyhedra: $\mathrm{VO}_{5}$ units; blue polyhedra: $\mathrm{WO}_{6}$ units. $\mathrm{VdW}$ van der Waals force. 
We also conducted IR measurements for $0,3.5$, and $40 \mathrm{~W}-\mathrm{V}$ to determine the effect of tungsten substitution on the structure (Supplementary Fig. 5). Although an obvious difference in the infrared (IR) spectra was not found for 3.5 and $0 \mathrm{~W}-\mathrm{V}$, the IR peak of $40 \mathrm{~W}-\mathrm{V}$ assigned to $\mathrm{V}=\mathrm{O}\left(1020 \mathrm{~cm}^{-1}\right)$ became weak compared to those of 0 and $3.5 \mathrm{~W}-\mathrm{V}$, results similar to those reported by Satsuma et al. ${ }^{56}$. The number of $\mathrm{V}=\mathrm{O}$ bonds would decrease to form $\mathrm{V}-\mathrm{O}-\mathrm{W}$ bonds by the addition of tungsten into the vanadium oxide lattice.

$\mathrm{NH}_{3}$-SCR activity of tungsten-substituted vanadium oxide. First, we investigated the effects of different amounts of tungsten on the $\mathrm{NH}_{3}-\mathrm{SCR}$ activity of $x \mathrm{~W}-\mathrm{V}$ catalysts under dry and wet (10 vol\% water) atmospheres at $150{ }^{\circ} \mathrm{C}$ (Fig. 3a). The $0 \mathrm{~W}-\mathrm{V}$ catalyst $\left(\mathrm{V}_{2} \mathrm{O}_{5}\right.$ without tungsten) showed $\mathrm{NO}$ conversions of $82 \%$ (dry) and $47 \%$ (wet). The NO conversion increased with an increase in the amount of tungsten up to $3.5 \mathrm{~mol} \%$. The NO conversions of $3.5 \mathrm{~W}-\mathrm{V}$ were $>99 \%$ (dry) and $94 \%$ (wet). The negative effect of water was suppressed by the incorporation of tungsten into vanadium oxide. The $3.5 \mathrm{~W}-\mathrm{V}$ catalyst showed the best $\mathrm{NH}_{3}$-SCR activity among the synthesized catalysts, while the NO conversion decreased with a further increase in the amount of tungsten. The $40 \mathrm{~W}-\mathrm{V}$ catalyst showed NO conversions of $29 \%$ (dry) and 19\% (wet). Thus, an excess amount of tungsten decreased the $\mathrm{NH}_{3}$-SCR activity.

The dependence of $\mathrm{NO}$ conversion on reaction temperature was examined for $0 \mathrm{~W}-\mathrm{V}, 3.5 \mathrm{~W}-\mathrm{V}$, and $1 \mathrm{wt} \% \mathrm{~V}_{2} \mathrm{O}_{5}-5 \mathrm{wt} \% \mathrm{WO}_{3} / \mathrm{TiO}_{2}$ $\left(\mathrm{V}-\mathrm{W} / \mathrm{TiO}_{2}\right.$, a model of an industrial catalyst; Fig. 3b). The $3.5 \mathrm{~W}-\mathrm{V}$ catalyst showed $\mathrm{NH}_{3}$-SCR activity at a low temperature $\left(<150^{\circ} \mathrm{C}\right)$ under both dry and wet conditions in which the conventional

a
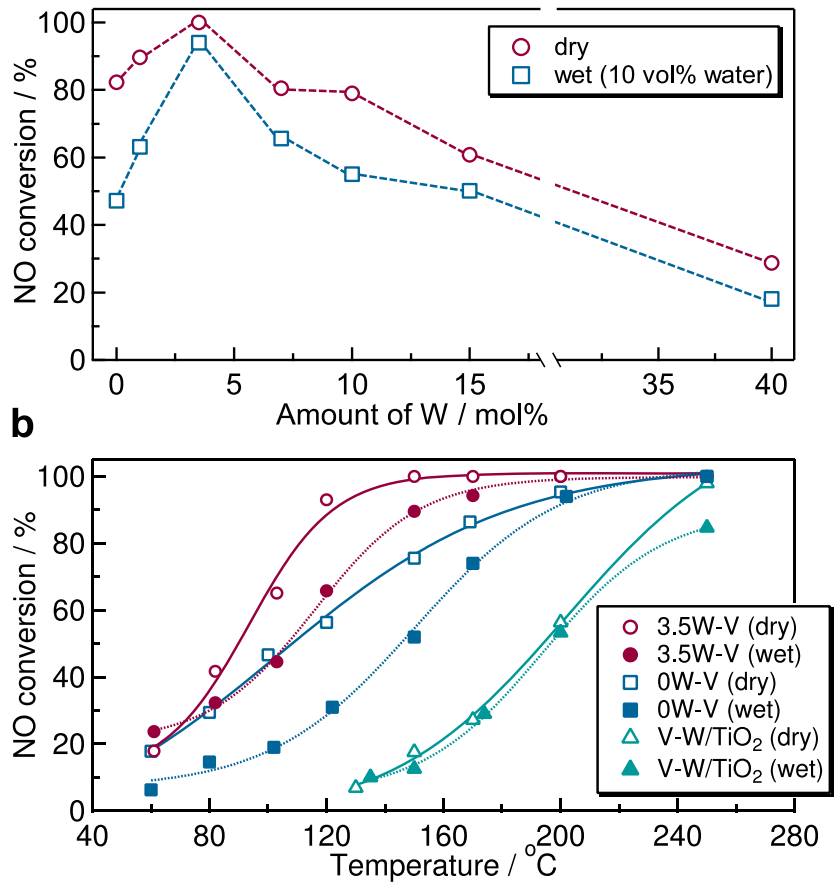

Fig. $3 \mathbf{N H}_{\mathbf{3}}-\mathrm{SCR}$ activity of $\mathbf{W}$-substituted vanadium oxide catalysts. a $\mathrm{NO}$ conversion $\left(150^{\circ} \mathrm{C}\right)$ of $\mathrm{W}$-substituted vanadium oxide catalysts as a function of the molar ratio of tungsten. $\mathbf{b} \mathrm{NO}$ conversion of $3.5 \mathrm{~W}-\mathrm{V}(\mathrm{W}-$ substituted vanadium oxide), OW- $\mathrm{V}$ (without tungsten), and $\mathrm{V}-\mathrm{W} / \mathrm{TiO}_{2}$ (model of a conventional catalyst) as a function of reaction temperature. Reaction conditions: the amount of the catalyst, $0.375 \mathrm{~g}$; reaction gas mixture, 250 ppm NO, $250 \mathrm{ppm} \mathrm{NH}_{3}, 4$ vol\% $\mathrm{O}_{2}$ and 10 vol\% $\mathrm{H}_{2} \mathrm{O}$ (when used) in Ar; flow rate, $250 \mathrm{~mL} \mathrm{~min}^{-1}$; space velocity, $40,000 \mathrm{~mL} \mathrm{~h}^{-1} \mathrm{~g}_{\text {cat }}{ }^{-1}$.
$\mathrm{V}-\mathrm{W} / \mathrm{TiO}_{2}$ catalyst did not show sufficient $\mathrm{NH}_{3}-\mathrm{SCR}$ activity. The $0 \mathrm{~W}-\mathrm{V}$ catalyst $\left(\mathrm{V}_{2} \mathrm{O}_{5}\right.$ without tungsten) also showed lowtemperature $\mathrm{NH}_{3}$-SCR activity under a dry condition, but the negative effect of water was critical at a low temperature. The temperatures for $80 \% \mathrm{NO}$ conversion $\left(T_{80}\right)$ were $110^{\circ} \mathrm{C}(3.5 \mathrm{~W}-\mathrm{V})$, $157^{\circ} \mathrm{C}(0 \mathrm{~W}-\mathrm{V})$, and $225^{\circ} \mathrm{C}\left(\mathrm{V}-\mathrm{W} / \mathrm{TiO}_{2}\right)$ under a dry condition and $135^{\circ} \mathrm{C}(3.5 \mathrm{~W}-\mathrm{V}), 178^{\circ} \mathrm{C}(0 \mathrm{~W}-\mathrm{V})$, and $236^{\circ} \mathrm{C}\left(\mathrm{V}-\mathrm{W} / \mathrm{TiO}_{2}\right)$ under a wet ( $10 \mathrm{vol} \%$ water) condition. $\mathrm{N}_{2}$ selectivity was $>99 \%$ during the reaction, and undesirable $\mathrm{N}_{2} \mathrm{O}$ production was not observed for any of the catalysts (Supplementary Fig. 6).

The effects of water concentration in flow gas on $\mathrm{NH}_{3}-\mathrm{SCR}$ were also investigated for $0 \mathrm{~W}-\mathrm{V}$ and $3.5 \mathrm{~W}-\mathrm{V}$ at $150{ }^{\circ} \mathrm{C}$ (Fig. $4 \mathrm{a}$ ). Although NO conversion of $3.5 \mathrm{~W}-\mathrm{V}$ was slightly decreased by the addition of $5 \%$ water into reaction gas, $\sim 93 \%$ NO conversion was maintained in the presence of $5-20$ vol\% of water. On the other hand, NO conversion was drastically decreased from $82 \%$ to $35 \%$ in the case of $0 \mathrm{~W}-\mathrm{V}$ when water vapor was introduced to the reaction gas. Although $\mathrm{NO}$ conversion decreased with the addition of water, the values were almost the same regardless of the concentration of water $(2-20 \%)$. Previous studies showed that a further inhibitory effect of water on the reaction rate did not occur at a high water concentration $(>5 \%)^{2,39,57}$. Water vapor would affect a catalytic cycle more strongly at a low temperature such as $150^{\circ} \mathrm{C}$. Thus, we found that tungsten-doped vanadium oxide $(3.5 \mathrm{~W}-\mathrm{V})$ shows a low-temperature $\mathrm{NH}_{3}$-SCR activity in the presence of a high concentration of water.

A catalytic stability test $\left(150^{\circ} \mathrm{C}\right)$ was conducted for $0 \mathrm{~W}-\mathrm{V}$ and $3.5 \mathrm{~W}-\mathrm{V}$ to determine the effect of tungsten on the stability (Fig. 4b). In the presence of $10 \mathrm{vol} \%$ water, the NO conversion was decreased for both $0 \mathrm{~W}-\mathrm{V}$ and $3.5 \mathrm{~W}-\mathrm{V}$. After turning off the water addition, the $\mathrm{NO}$ conversion of $3.5 \mathrm{~W}-\mathrm{V}$ recovered to the original value $(>99 \%)$, but that of $0 \mathrm{~W}-\mathrm{V}$ decreased from 78 to $59 \%$. The specific surface areas of 0 and $3.5 \mathrm{~W}-\mathrm{V}$ were measured before and after the catalytic stability test (Fig. 4c). The specific surface area of $0 \mathrm{~W}-\mathrm{V}$ decreased after the stability test $(41 \rightarrow 19$ $\left.\mathrm{m}^{2} \mathrm{~g}^{-1}\right)$, while $3.5 \mathrm{~W}-\mathrm{V}$ had the same value $\left(39 \mathrm{~m}^{2} \mathrm{~g}^{-1}\right)$. Although a porous structure was confirmed by scanning electron microscope measurement for $0 \mathrm{~W}-\mathrm{V}$ before the activity test, it disappeared and the surface became smooth after the test (Supplementary Fig. 7). Obvious morphological changes were not confirmed for $3.5 \mathrm{~W}-\mathrm{V}$. There were no changes in the XRD patterns of 0 and $3.5 \mathrm{~W}-\mathrm{V}$ after the stability test (Supplementary Fig. 8). We assume that the bulk tungsten sites, which have a three-dimensional coordination environment ( $\mathrm{WO}_{6}$ units), retain the structure by incorporation into the layered vanadium oxide lattice, leading to the retention of surface area.

Reaction kinetics of tungsten-substituted vanadium oxide catalysts. Reaction rate, apparent activation energy $\left(E_{\mathrm{a}}\right)$, and reaction order were investigated to understand the reaction kinetics for low-temperature $\mathrm{NH}_{3}$-SCR. Reaction rates for the kinetics were calculated by adjusting the weights of the catalysts to control the conversion to $<20 \%$. Reaction rates per surface area were $3.2 \times 10^{-9}$ $(0 \mathrm{~W}-\mathrm{V}), 5.2 \times 10^{-9}(3.5 \mathrm{~W}-\mathrm{V})$, and $0.2 \times 10^{-9} \mathrm{~mol}_{\mathrm{NO}} \mathrm{m}^{-2} \mathrm{~s}^{-1}$ $\left(\mathrm{V}-\mathrm{W} / \mathrm{TiO}_{2}\right.$ ) in a dry condition (Fig. 5a and Supplementary Table 3), indicating that the reaction site of $3.5 \mathrm{~W}-\mathrm{V}$ was favorable for $\mathrm{NH}_{3}$-SCR to proceed compared to the reaction sites of $0 \mathrm{~W}-\mathrm{V}$ and $\mathrm{V}-\mathrm{W} / \mathrm{TiO}_{2}$. The reaction rate of $0 \mathrm{~W}-\mathrm{V}$ considerably decreased to $1.4 \times 10^{-9} \mathrm{~mol}_{\mathrm{NO}} \mathrm{m}^{-2} \mathrm{~s}^{-1}$ in a wet condition and that of $3.5 \mathrm{~W}-\mathrm{V}$ was $4.2 \times 10^{-9} \mathrm{~mol}_{\mathrm{NO}} \mathrm{m}^{-2} \mathrm{~s}^{-1}$. Thus, the inhibitory effect of water on the reaction was less for the tungsten-substituted vanadium oxide catalyst.

The apparent activation energy $\left(E_{\mathrm{a}}\right)$ values calculated from Arrhenius plots were $39 \mathrm{~kJ} \mathrm{~mol}^{-1}(0 \mathrm{~W}-\mathrm{V})$ and $36 \mathrm{~kJ} \mathrm{~mol}^{-1}$ $(3.5 \mathrm{~W}-\mathrm{V})$ under a dry condition (Fig. $5 \mathrm{~b}$ and Supplementary 

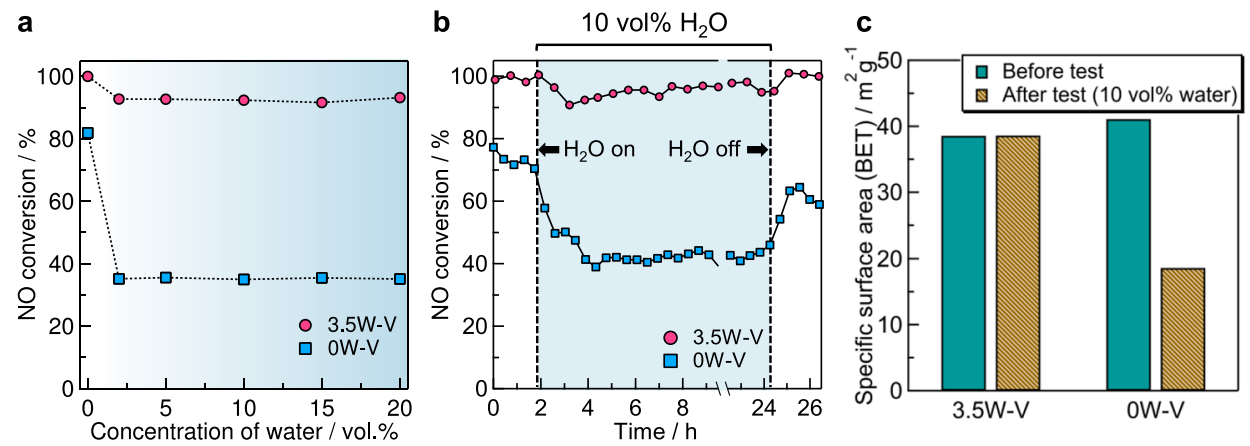

Fig. 4 Water tolerance of $\mathbf{W}$-substituted vanadium oxide catalysts. a $\mathrm{NO}$ conversion $\left(150^{\circ} \mathrm{C}\right)$ of $3.5 \mathrm{~W}-\mathrm{V}$ (W-substituted vanadium oxide) and $\mathrm{OW}-\mathrm{V}$ (without tungsten) as a function of the concentration of water. $\mathbf{b}$ Catalytic stability test $\left(150^{\circ} \mathrm{C}\right)$ of $3.5 \mathrm{~W}-\mathrm{V}$ and $\mathrm{OW}-\mathrm{V}$. Reaction conditions: the amount of the catalyst, $0.375 \mathrm{~g}$; reaction gas mixture, $250 \mathrm{ppm} \mathrm{NO}, 250$ ppm NH $\mathrm{N}_{3}, 4$ vol\% $\mathrm{O}_{2}$ and 2-20 vol\% $\mathrm{H}_{2} \mathrm{O}$ (when used) in Ar; flow rate, $250 \mathrm{~mL}$ min ${ }^{-1}$; space velocity, $40,000 \mathrm{~mL} \mathrm{~h}^{-1} \mathrm{gcat}^{-1}$. c Specific surface areas of $3.5 \mathrm{~W}-\mathrm{V}$ and $\mathrm{OW}-\mathrm{V}$ before and after a stability test.
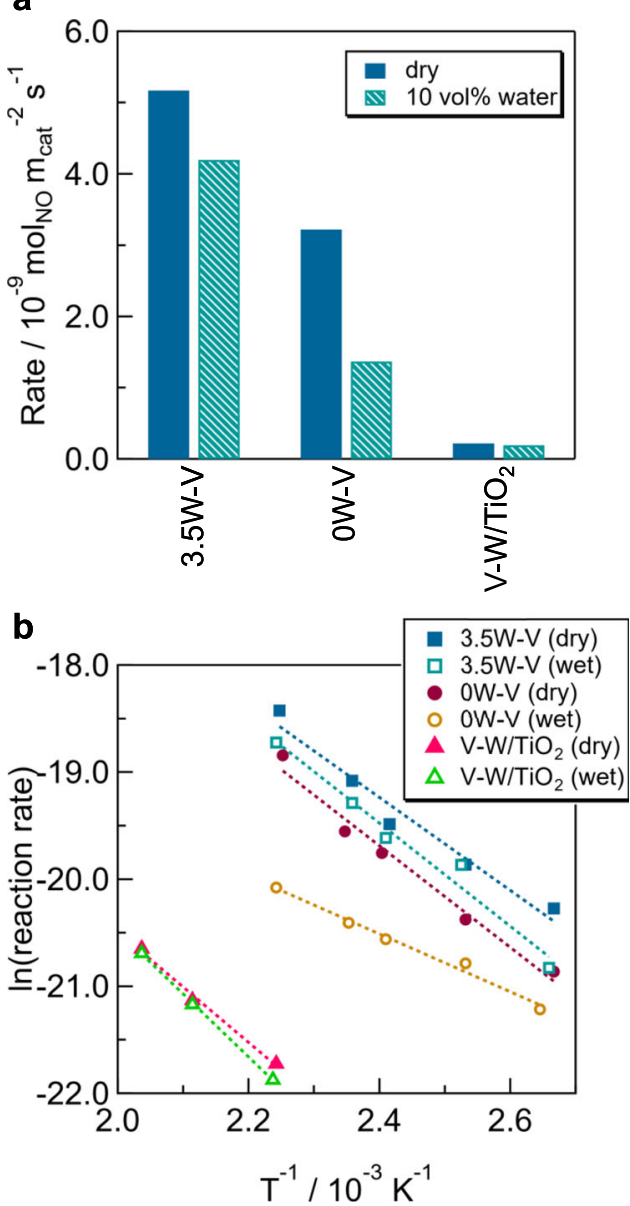

Fig. 5 Kinetic measurements for $\mathbf{N H}_{\mathbf{3}}$-SCR. a Reaction rate per specific surface area at $150^{\circ} \mathrm{C}$ and $\mathbf{b}$ Arrhenius plots for $3.5 \mathrm{~W}-\mathrm{V}$ (W-substituted vanadium oxide), $\mathrm{OW}-\mathrm{V}$ (without tungsten), and $\mathrm{V}-\mathrm{W} / \mathrm{TiO}_{2}$ (model of a conventional catalyst) at $150^{\circ} \mathrm{C}$ under a dry condition and wet condition (10 vol\% water).

Table 3), indicating that the reaction mechanisms were similar under a dry condition. $E_{\mathrm{a}}$ of $3.5 \mathrm{~W}-\mathrm{V}$ under a wet condition was $40 \mathrm{~kJ} \mathrm{~mol}^{-1}$, which was close to that under a dry condition, but that of $0 \mathrm{~W}-\mathrm{V}$ was $22 \mathrm{~kJ} \mathrm{~mol}^{-1}$ and preexponential factor (intercept of the line) decreased in the presence of water vapor. The change in $E_{\mathrm{a}}$ of $0 \mathrm{~W}-\mathrm{V}$ reflects the different reaction mechanism of vanadium oxide without tungsten. Although the $E_{\mathrm{a}}$ of $0 \mathrm{~W}-\mathrm{V}$ became smaller, the number of active sites (preexponential factor) would decrease because of its blockage by water, leading to a decrease in the activity. $E_{\mathrm{a}}$ values of $\mathrm{V}-\mathrm{W} /$ $\mathrm{TiO}_{2}$ were 43 (dry) and $49 \mathrm{~kJ} \mathrm{~mol}^{-1}$ (wet). Therefore, the effect of tungsten on the $\mathrm{NH}_{3}$-SCR cycle would be similar to that in the bulk $\mathrm{V}-\mathrm{W}$ oxide system.

The $\mathrm{NH}_{3}$-SCR of a vanadium-based catalyst proceeds as follows: (1) adsorption of $\mathrm{NH}_{3}$ on an acid site, (2) reaction of $\mathrm{NO}$ with $\mathrm{NH}_{3}$ to produce $\mathrm{N}_{2}+\mathrm{H}_{2} \mathrm{O}$ via a nitrosamide $\left(\mathrm{NH}_{2} \mathrm{NO}^{*}\right)$ intermediate with simultaneous reduction of the vanadia surface, and (3) reoxidation of the partially reduced vanadia surface by oxygen molecules $1,52,53$. Therefore, we measured the reaction orders for $\mathrm{NH}_{3}, \mathrm{NO}$, and $\mathrm{O}_{2}$ at $150{ }^{\circ} \mathrm{C}$ (Supplementary Fig. 9 and Supplementary Table 3). Ranges of gas concentration were 125-500 ppm for $\mathrm{NH}_{3}, 125-500 \mathrm{ppm}$ for $\mathrm{NO}$, and $2-8 \%$ for $\mathrm{O}_{2}$. Reaction orders of $0 \mathrm{~W}-\mathrm{V}$ and $3.5 \mathrm{~W}-\mathrm{V}$ were $0.2-0.3\left(\mathrm{NH}_{3}\right), 0.9-1.1$ (NO), and 0.3-0.4 $\left(\mathrm{O}_{2}\right)$ under both dry and wet atmospheres. The small reaction order for $\mathrm{NH}_{3}$ indicates that the adsorption of $\mathrm{NH}_{3}$ to the catalyst surface is strong. The reaction order for NO was high compared to those for the other substrates, indicating that the reaction rate depended on $\mathrm{NO}$ concentration in actual conditions. The reaction order for $\mathrm{O}_{2}$ was $0.3-0.4$ at $150^{\circ} \mathrm{C}$, although zeroorder dependence was reported at $\mathrm{O}_{2}$ concentrations $>1 \%$ at a higher temperature $\left(>250^{\circ} \mathrm{C}\right)$ for a supported vanadia catalyst ${ }^{2,38,53}$. Oxygen molecules contribute to the re-oxidation step of the partially reduced vanadia surface $\left(\mathrm{V}^{4+} \rightarrow \mathrm{V}^{5+}\right)$ in the reaction mechanism of $\mathrm{NH}_{3}$-SCR. However, the re-oxidation rate can be slower for a low temperature and the surface of the catalyst is not fully oxidized in a low-temperature range $2,38,53,54$.

Roles of tungsten substitution in the $\mathrm{NH}_{3}$-SCR cycle. We carried out operando IR and UV-Vis measurements at $150{ }^{\circ} \mathrm{C}$ to examine the reaction mechanism of $\mathrm{NH}_{3}$-SCR over tungstensubstituted vanadium oxide catalysts at a low temperature. To observe the behavior of acid sites, we conducted operando IR measurements for $0 \mathrm{~W}-\mathrm{V}\left(\mathrm{V}_{2} \mathrm{O}_{5}\right.$ without tungsten), $3.5 \mathrm{~W}-\mathrm{V}$ (the most active catalyst), and $40 \mathrm{~W}-\mathrm{V}$ (with excess tungsten) as shown in Fig. 6. We flowed $0.1 \% \mathrm{NH}_{3} / \mathrm{He}$ to the IR discs of the catalysts to adsorb ammonia and purged excess ammonia with He. Then, the time course of the IR spectra was monitored under the condition of $500 \mathrm{ppm} \mathrm{NO}+8 \% \mathrm{O}_{2} / \mathrm{He}$ flow with simultaneous detection of $\mathrm{N}_{2}$ by a mass spectrometer (MS) equipped at the outlet of the IR cell. During this measurement, adsorbed $\mathrm{NH}_{3}$ reacts with NO followed by reduction of redox-active sites. Then, reduced sites are re-oxidized by oxygen. The reaction would continue until adsorbed $\mathrm{NH}_{3}$ is completely consumed (Supplementary Fig. 10). The amount of ammonia species adsorbed on Lewis and Brønsted acid sites was calculated from the area of corresponding IR peaks. Under the dry condition, IR peaks 
a

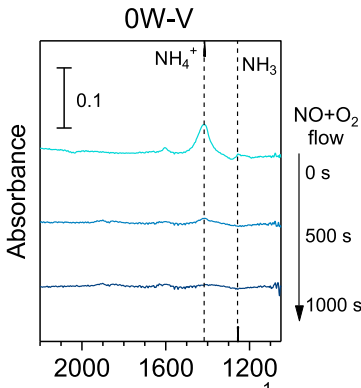

d

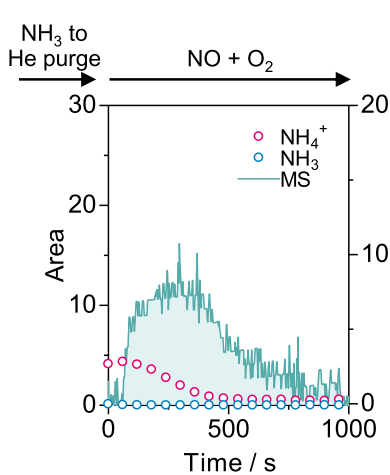

b

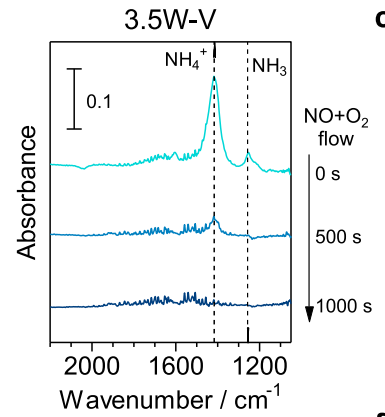

C

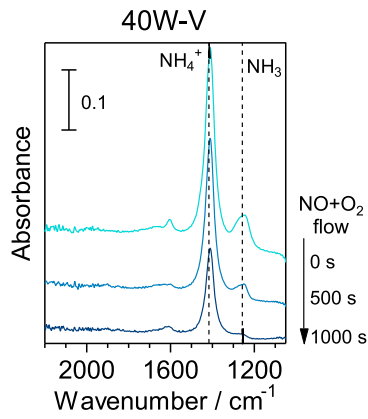

。

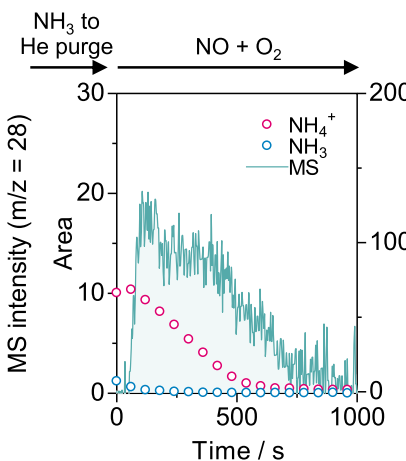

f

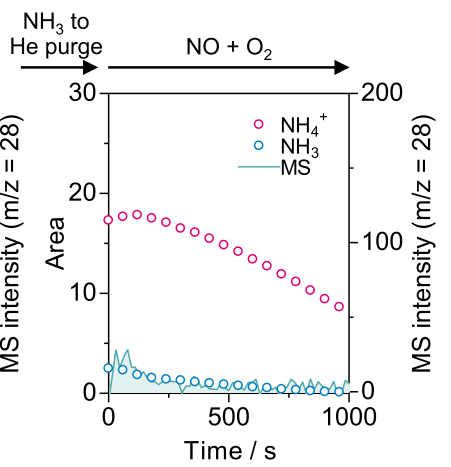

Fig. 6 Acid properties under a dry atmosphere. a-c Operando IR spectra of ad species on OW-V (without tungsten), 3.5W-V (with tungsten), and 40W-V (excess tungsten) during $\mathrm{NH}_{3}$ adsorption followed by $\mathrm{NO}+\mathrm{O}_{2}$ exposure at $150{ }^{\circ} \mathrm{C}$ under a dry condition. The IR disc was exposed to $0.1 \% \mathrm{NH} / \mathrm{He}$ flow (30 $\mathrm{min}$ ) and purged with $\mathrm{He}\left(20 \mathrm{~min}\right.$ ), followed by exposure to $500 \mathrm{ppm} \mathrm{NO}+8 \% \mathrm{O}_{2}$ (He balance) flow. $\mathbf{d}$-f IR peak areas of ammonia species adsorbed on Lewis acid sites $\left(\mathrm{NH}_{3}\right)$ and Brønsted acid sites $\left(\mathrm{NH}_{4}{ }^{+}\right)$and $\mathrm{MS}$ intensity of $\mathrm{N}_{2}$ versus time of $\mathrm{NO}+\mathrm{O}_{2}$ flowing.

assigned to $\mathrm{NH}_{3}$ adsorbed on the Lewis acid site $\left(1250-1254 \mathrm{~cm}^{-1}\right)$ and $\mathrm{NH}_{4}{ }^{+}$adsorbed on Brønsted acid site $\left(1410-1420 \mathrm{~cm}^{-1}\right)$ were observed for $0,3.5$, and $40 \mathrm{~W}-\mathrm{V}$ after the adsorption of ammonia (Fig. 6a-c). The relative amounts of Lewis and Brønsted acid sites, which were calculated from the area of initial IR peaks after ammonia adsorption (spectra at $0 \mathrm{~s}$ in Fig. 6a-c), were summarized in Fig. 7a. The numbers of acid sites increased from 0.1 to 2.5 (Lewis acid, $\mathrm{NH}_{3}$ ) and from 4.1 to 17.3 (Brønsted acid, $\mathrm{NH}_{4}{ }^{+}$) with an increase in the molar ratio of tungsten in the catalysts up to $40 \mathrm{~mol} \%$. The results indicate that both Lewis and Brønsted acid sites are created by the incorporation of tungsten. The areas of the IR peaks for $\mathrm{NH}_{3}$ and $\mathrm{NH}_{4}{ }^{+}$decreased with time of $\mathrm{NO}+\mathrm{O}_{2}$ flow for $1000 \mathrm{~s}$ (Fig. 6a-c and $\mathrm{d}-\mathrm{f}$, red and blue lines). The consumption of ammonia species was completed within $500 \mathrm{~s}$ for 0 and $3.5 \mathrm{~W}-\mathrm{V}$, while $40 \mathrm{~W}-\mathrm{V}$ showed a slow consumption rate. We also confirmed $\mathrm{N}_{2}$ production upon the introduction of $\mathrm{NO}+$ $\mathrm{O}_{2}$, and a greater amount of $\mathrm{N}_{2}$ was observed for $3.5 \mathrm{~W}-\mathrm{V}$ than for $0 \mathrm{~W}-\mathrm{V}$ (Fig. $6 \mathrm{~d}$, e, mass spectra), indicating that the production of $\mathrm{N}_{2}$ was facilitated by the addition of tungsten. On the other hand, the MS intensity of $\mathrm{N}_{2}$ was considerably low for $40 \mathrm{~W}-\mathrm{V}$ (Fig. $6 \mathrm{f}$, mass spectra). These results suggested that $\mathrm{NH}_{3}$-SCR activity decreases when an excess amount of tungsten is introduced to vanadium oxide because of high tungsten coverage that leads to blocking of the surface vanadium species as catalytically active sites despite the increase in acid sites.

To investigate the redox properties of the catalysts, we also conducted operando UV-Vis measurements (Fig. $7 \mathrm{~b}$ and Supplementary Figs. 11 and 12). We monitored the change in the pseudo-absorbance (Kubelka-Munk unit) of UV-Vis spectra at $\lambda=700 \mathrm{~nm}\left(\Delta \mathrm{KM}_{700}\right)$, which is assigned to the $d-d$ transition of $\mathrm{V}^{4+}$, to observe the change in the valence of vanadium sites $\left(\mathrm{V}^{5+} \leftrightarrow \mathrm{V}^{4+}\right)$. The production of $\mathrm{N}_{2}$ was recorded simultaneously by an MS. The monitoring was performed under $\mathrm{NO}+\mathrm{NH}_{3}$ flowing followed by $\mathrm{O}_{2}$ flowing to evaluate the respective reduction and oxidation half-cycles. The correlations between
$\mathrm{W}$ content, amount of $\mathrm{V}^{5+}$ reduced by $\mathrm{NO}+\mathrm{NH}_{3}\left(\Delta \mathrm{KM}_{700}\right.$ under $\mathrm{NO}+\mathrm{NH}_{3}$ flowing), and MS intensity for $\mathrm{N}_{2}$ are shown in Fig. 7b. The $3.5 \mathrm{~W}-\mathrm{V}$ showed the largest $\Delta \mathrm{KM}_{700}$ and $\mathrm{MS}$ intensity of $\mathrm{N}_{2}$ and had superior reduction capability for the production of $\mathrm{N}_{2}$. On the other hand, $\Delta \mathrm{KM}_{700}$ considerably decreased when $40 \mathrm{~mol} \%$ of tungsten was doped, indicating that the catalyst with an excess amount of tungsten was difficult to be reduced. The $3.5 \mathrm{~W}-\mathrm{V}$ also showed the largest $\Delta \mathrm{KM}_{700}$ under $\mathrm{O}_{2}$ flowing (Supplementary Figs. 11b, d, f and 12b). Thus, $3.5 \mathrm{~W}-\mathrm{V}$ with moderate tungsten loading turned out to be the most redoxactive catalyst, leading to the largest $\mathrm{N}_{2}$ production. Combining with the results of operando IR measurements, tungsten sites serve as acid sites for the adsorption of ammonia, which is stronger than those pre-existing in vanadium oxide without tungsten, and the vanadium $\left(\mathrm{V}^{5+}\right)$ sites work as redox sites for $\mathrm{NH}_{3}$-SCR. The highest activity for $3.5 \mathrm{~W}-\mathrm{V}$ can be ascribed to the increase in the number of acid sites and the high redox capability of the surface $\mathrm{V}$ species. $\mathrm{W}-\mathrm{O}-\mathrm{V}$ units would be needed for the progression of the reaction, and the number of adjacent tungsten sites such as $\mathrm{W}-\mathrm{O}-\mathrm{W}$ units becomes dominant with an increase in the amount of tungsten, leading to blocking of the surface redox-active $\mathrm{V}$ sites and thus resulting in a decrease in activity.

Effects of water on the $\mathrm{NH}_{3}$-SCR cycle. The activity test clearly showed a positive effect of tungsten substitution in the presence of water. We also conducted operando IR measurements under a wet condition ( 2 vol\% water) to check the effect of water on the acid sites for $0 \mathrm{~W}-\mathrm{V}$ and $3.5 \mathrm{~W}-\mathrm{V}$. Although the IR peaks of adsorbed ammonia species on Lewis and Brønsted acid sites $\left(\mathrm{NH}_{3}\right.$ and $\mathrm{NH}_{4}{ }^{+}$, respectively) were both observed under a dry condition, the absorption band attributed to the $\mathrm{NH}_{4}{ }^{+}$species was exclusively seen in the presence of water (Fig. 8a, b). The areas of the IR absorption band for Lewis and Brønsted acid sites under dry and wet conditions are shown in Fig. 8e, f. The area of 
a
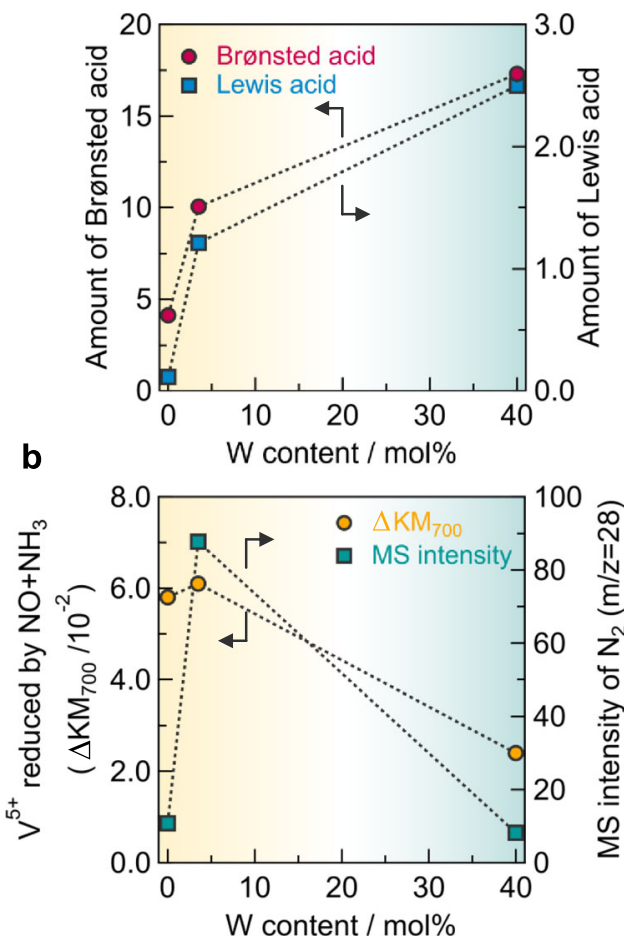

Fig. 7 Effect of tungsten on acid and redox properties. a Amount of Lewis and Brønsted acid sites as a function of $W$ content. The amount of both acid sites was observed from the area of initial IR spectra after ammonia adsorption (spectra at $\mathrm{O} s$ in Fig. $6 \mathrm{a}-\mathrm{c}$ ). $\mathbf{b}$ Amount of $\mathrm{V}^{5+}$ reduced by $\mathrm{NO}+$ $\mathrm{NH}_{3}$ and $\mathrm{MS}$ intensity of $\mathrm{N}_{2}$ produced as a function of $\mathrm{W}$ content. The amount of $\mathrm{V}^{5+}$ reduced was determined from the change in the Kubelka-Munk unit at $\lambda=700 \mathrm{~nm}\left(\Delta \mathrm{KM}_{700}\right)$ under $\mathrm{NO}(500 \mathrm{ppm})+\mathrm{NH}_{3}$ (500 ppm) flowing (1500 s) at $150^{\circ} \mathrm{C}$ under a dry atmosphere shown in Supplementary Figs. 7 and 8 a.

the IR absorption band for $\mathrm{NH}_{4}{ }^{+}$(Brønsted acid sites) increased from 10.0 (dry) to 18.7 (wet) and that for $\mathrm{NH}_{3}$ (Lewis acid sites) decreased from 1.21 (dry) to 0.27 (wet) in the case of $3.5 \mathrm{~W}-\mathrm{V}$ when water vapor was introduced (3.5W-V; Fig. $8 \mathrm{~d}-\mathrm{f})$. On the other hand, $0 \mathrm{~W}-\mathrm{V}$ showed only a slight change in the distribution of acid sites (0W-V; Fig. 8c, e, f). On a metal oxide surface, Lewis acid sites (coordinatively unsaturated metal cations) and Brønsted base sites (oxygen ions) can be changed into Brønsted acid sites by dissociative adsorption of water ${ }^{58}$. In a previous study, it was theoretically predicted that Brønsted acid sites (hydroxyl groups) are newly created on the $\mathrm{V}_{2} \mathrm{O}_{5}-\mathrm{WO}_{3}$ solid solution by dissociative adsorption of water on tungstenexposed sites and bridging oxygen sites under a wet atmosphere (Fig. 8g) ${ }^{48}$. On the other hand, water could be adsorbed on $\mathrm{V}_{2} \mathrm{O}_{5}$ without tungsten, but a Brønsted acid site does not form ${ }^{47,48}$. The observed changes in the surface state of vanadium oxide with and without tungsten can reflect such theoretical predictions. The area of the IR spectra $\left(\mathrm{NH}_{4}^{+}\right)$decreased with time of $\mathrm{NO}+\mathrm{O}_{2}$ flowing both for $3.5 \mathrm{~W}-\mathrm{V}$ and $0 \mathrm{~W}-\mathrm{V}$ (Fig. $8 \mathrm{c}$, d, red and blue lines), and ammonia species were consumed by the reaction under a wet condition. Considerable $\mathrm{N}_{2}$ production was confirmed for $3.5 \mathrm{~W}-\mathrm{V}$ under a wet condition, but the $\mathrm{N}_{2}$ production of $0 \mathrm{~W}-\mathrm{V}$ was smaller than that under a dry condition (Fig. $8 \mathrm{c}, \mathrm{d}$, mass spectra). These results suggest that $\mathrm{NH}_{3}$-SCR of bulk vanadium oxide without tungsten is strongly inhibited by water, while bulk tungsten-substituted vanadium oxide proceeds with the reaction by newly created protonic Brønsted acid sites that are less affected by water.

Operando UV-Vis measurements were also conducted for $3.5 \mathrm{~W}-\mathrm{V}$ with and without water vapor to check the redox cycle (Fig. 9 and Supplementary Fig. 13). $\mathrm{NO}(500 \mathrm{ppm})+\mathrm{NH}_{3}$ $(500 \mathrm{ppm})$ and $\mathrm{O}_{2}(8 \%)$ were repetitively introduced three times to confirm the redox cycle. During the measurements under wet and dry conditions, the pseudo-absorbance (KM unit) at $\lambda=700 \mathrm{~nm}$ similarly increased and decreased under $\mathrm{NO}+\mathrm{NH}_{3}$ and $\mathrm{O}_{2}$ flowing, showing reduction $\left(\mathrm{V}^{5+} \rightarrow \mathrm{V}^{4+}\right)$ and oxidation $\left(\mathrm{V}^{4+} \rightarrow \mathrm{V}^{5+}\right)$ halfcycles (Fig. 9a-c for a wet condition and Supplementary Fig. 13 for a dry condition). The times of change in pseudo-absorbance (KM unit) at $\lambda=700 \mathrm{~nm}$ are shown by blue (wet) and red (dry) solid lines in Fig. 9d. Repetitive production of $\mathrm{N}_{2}$ with a change in $\Delta \mathrm{KM}_{700}$ was confirmed under both dry and wet atmospheres (Fig. 9d). Notably, considerable $\mathrm{N}_{2}$ production was seen even in the presence of water (Fig. 9d, mass spectra). These results demonstrate that $3.5 \mathrm{~W}-\mathrm{V}$ proceeds with $\mathrm{NH}_{3}$-SCR by the redox cycle and the $\mathrm{N}_{2}$ production is not affected by water in a transient state.

Difference between supported and bulk vanadium oxide. Operando IR spectra were observed for $3.5 \mathrm{~W}-\mathrm{V}$ and $\mathrm{V}-\mathrm{W} / \mathrm{TiO}_{2}$ to consider the difference between bulk and supported tungstensubstituted vanadium oxide catalysts. The measurement was conducted at $200{ }^{\circ} \mathrm{C}$ at which $\mathrm{V}-\mathrm{W} / \mathrm{TiO}_{2}$ is sufficiently active and $\mathrm{NO}$ was flowed into samples after adsorption of $\mathrm{NH}_{3}$ to obtain the information of acid sites next to redox sites (Supplementary Fig. 14). After the adsorption of $\mathrm{NH}_{3}$ under a wet condition, $\mathrm{NH}_{4}{ }^{+}$species adsorbed on Brønsted acid sites were solely confirmed for $3.5 \mathrm{~W}-\mathrm{V}$ (Fig. 10a), which was a similar result obtained at $150{ }^{\circ} \mathrm{C}$ in the presence of water. $\mathrm{NH}_{4}{ }^{+}$species were rapidly consumed and significant $\mathrm{N}_{2}$ production was confirmed when $\mathrm{NO}$ flowed (Fig. 10c). On the other hand, $\mathrm{NH}_{3}$ species adsorbed on Lewis acid sites were mainly observed in addition to $\mathrm{NH}_{4}{ }^{+}$ species for $\mathrm{V}-\mathrm{W} / \mathrm{TiO}_{2}$ (Fig. 10b). However, the consumption of $\mathrm{NH}_{4}{ }^{+}$and $\mathrm{NH}_{3}$ species were dull and $\mathrm{N}_{2}$ production was less (Fig. 10c). The results demonstrate that Brønsted acid sites of $3.5 \mathrm{~W}-\mathrm{V}$ are more reactive than Brønsted and Lewis acid sites of $\mathrm{V}-\mathrm{W} / \mathrm{TiO}_{2}$. After the above operando IR measurement under NO flowing for $3.5 \mathrm{~W}-\mathrm{V}$, the sample was oxidized and NO flowed again to check if the residual $\mathrm{NH}_{4}{ }^{+}$reacts with $\mathrm{NO}$. Although the $\mathrm{N}_{2}$ production and the consumption of $\mathrm{NH}_{4}{ }^{+}$were attenuated under the first $\mathrm{NO}$ flowing (Fig. 10c), $\mathrm{NH}_{4}{ }^{+}$species on Brønsted acid sites were consumed again and $\mathrm{N}_{2}$ production was confirmed under the second NO flowing after oxidation (Supplementary Fig. 15). If Operando UV-Vis measurement was conducted in the same procedure $\left(\mathrm{NH}_{3} \rightarrow 1\right.$ st $\mathrm{NO} \rightarrow \mathrm{O}_{2} \rightarrow 2$ nd $\mathrm{NO}$ ), the similar $\mathrm{N}_{2}$ production behavior was observed accompanied by redox cycle $\left(\mathrm{V}^{5+} \leftrightarrow \mathrm{V}^{4+}\right)$ under the first and second $\mathrm{NO}$ flowing (Supplementary Fig. 16). These results show that V sites reduced by the reaction of $\mathrm{NH}_{4}{ }^{+}$(Brønsted acid site) with $\mathrm{NO}$ are reoxidized, and remaining ammonia species move to Brønsted acid sites which are adjacent to redox $\mathrm{V}$ sites, then they react with $\mathrm{NO}$ by the re-oxidized $\mathrm{V}$ sites again. According to the previous reports on supported vanadium-based catalysts, Brønsted acid sites are not directly involved in the catalytic cycle and they play a role in an $\mathrm{NH}_{3}$ pool to supply $\mathrm{NH}_{3}$ to the Lewis acid sites ${ }^{20,52}$. In the case of bulk tungsten-substituted vanadium oxide catalyst, Brønsted acid site (B) would be located next to redox-active $\mathrm{V}^{5+}$ site and it would directly react with $\mathrm{NO}$ as following reduction half-cycle:

$$
\mathrm{V}(\mathrm{V})=\mathrm{O}+\mathrm{NH}_{3}(\mathrm{~B})+\mathrm{NO} \rightarrow \mathrm{V}(\mathrm{IV})-\mathrm{OH}+\mathrm{N}_{2}+\mathrm{H}_{2} \mathrm{O} .
$$


a $\mathrm{OW}-\mathrm{V}(2 \mathrm{vol} \%$ water $)$

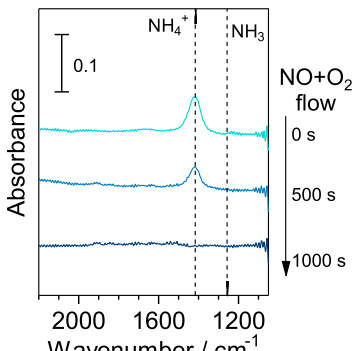

C

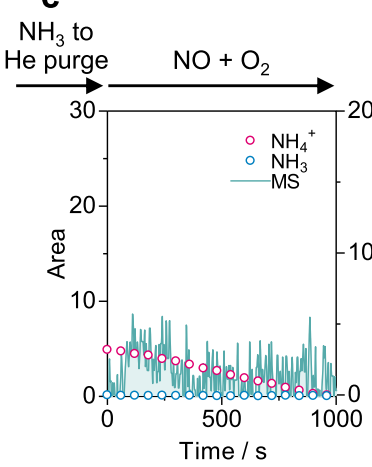

b $3.5 \mathrm{~W}-\mathrm{V}(2 \mathrm{vol} \%$ water $)$

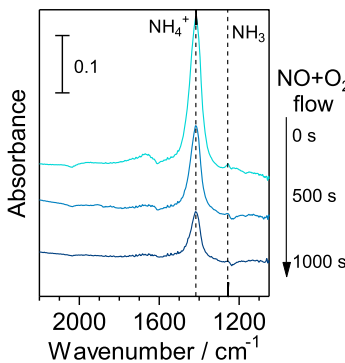

Wavenumber $/ \mathrm{cm}^{-1}$

$\mathrm{NH}_{3}$ to

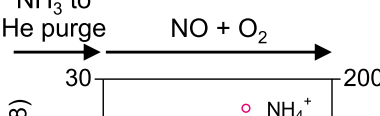

200

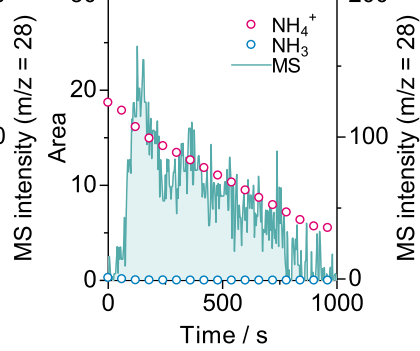

e Lewis acid $\left(\mathrm{NH}_{3}\right)$

f Brønsted acid $\left(\mathrm{NH}_{4}^{+}\right)$

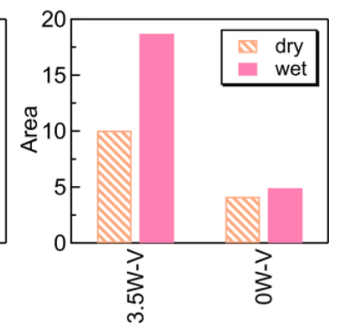

g

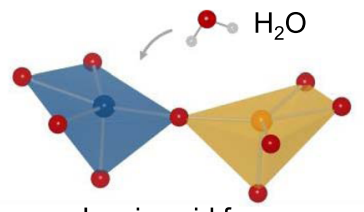

Lewis acid form

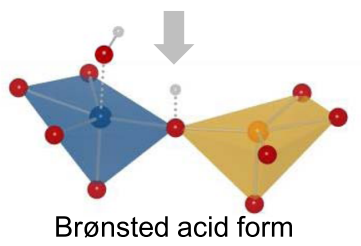

Fig. 8 Acid properties in the presence of water vapor. $\mathbf{a}$, b Operando IR spectra of ad species on OW-V (without tungsten) and 3.5W-V (with tungsten) during $\mathrm{NH}_{3}$ adsorption, followed by $\mathrm{NO}+\mathrm{O}_{2}$ exposure at $150^{\circ} \mathrm{C}$ under a wet condition ( 2 vol\% water). The IR disc was exposed to $0.1 \% \mathrm{NH} / \mathrm{He}$ flow (30 min) and purged with $\mathrm{He}(20 \mathrm{~min})$, followed by exposure to $500 \mathrm{ppm} \mathrm{NO}+8 \% \mathrm{O}_{2}+2 \% \mathrm{H}_{2} \mathrm{O}$ (He balance) flow. c, $\mathbf{d}$ The IR peak areas of $\mathrm{NH}_{3}$ adsorbed on Lewis acid sites $\left(\mathrm{NH}_{3}\right)$ and Brønsted acid sites $\left(\mathrm{NH}_{4}{ }^{+}\right)$and $\mathrm{MS}$ intensity of $\mathrm{N}_{2}$ versus time of $\mathrm{NO}+\mathrm{O}_{2}$ flowing. IR areas for $\mathbf{e}$ Lewis acid and f Brønsted acid measured from IR spectra ( $\mathrm{O}$ s) under dry and wet conditions. $\mathbf{g}$ Metal-exposed surface of W-substituted vanadium oxide and its changes from Lewis acid form to Brønsted acid form. Orange polyhedra: vanadium units; blue polyhedra: tungsten units.

Furthermore, we conducted temperature-programmed reaction measurements under $\mathrm{NO}+\mathrm{NH}_{3}$ flow for $3.5 \mathrm{~W}-\mathrm{V}$ and $\mathrm{V}-\mathrm{W} /$ $\mathrm{TiO}_{2}$ (Supplementary Fig. 17) to observe the reducibility. The reduction of $3.5 \mathrm{~W}-\mathrm{V}$ started at ambient temperature, while a higher temperature was needed to reduce $\mathrm{V}-\mathrm{W} / \mathrm{TiO}_{2}$. Bulk tungsten-substituted vanadium oxide catalyst has water-tolerant Brønsted acid sites and greater reducibility originated from bulk characteristics, resulting in high $\mathrm{NH}_{3}$-SCR activity at a low temperature in the presence of water vapor.

\section{Discussion}

We investigated the low-temperature $\mathrm{NH}_{3}$-SCR activity of tungsten-substituted vanadium oxide and the reaction mechanism under dry and wet conditions. The catalysts, $0-40 \mathrm{~mol} \%$ tungsten-substituted vanadium oxide, were synthesized from ammonium metavanadate $\left(\mathrm{NH}_{4} \mathrm{VO}_{3}\right)$ and ammonium metatungstate by the oxalate method. We confirmed from atomicresolution HAADF-STEM images that the lattice vanadium sites were substituted by tungsten atoms, while adjacent and cluster tungsten moieties were found when an excess amount of tungsten was doped up to $40 \mathrm{~mol} \%$. XRD measurements also showed that the $\mathrm{WO}_{3}$ phase was generated in catalysts with an increase in the molar ratio of $>3.5 \mathrm{~mol} \%$. The $3.5 \mathrm{~W}-\mathrm{V}$ catalyst showed the highest NO conversions, $>99 \%$ (dry) and $~ 93 \%$ (wet, 10 vol\% water). The NO conversion decreased when $>3.5 \mathrm{~mol} \%$ of tungsten was added to vanadium oxide. The stability of the catalysts was increased by the addition of tungsten because bulk $\mathrm{WO}_{6}$ units connected vanadium oxide layers. The reaction mechanism was investigated for $0 \mathrm{~W}-\mathrm{V}\left(\mathrm{V}_{2} \mathrm{O}_{5}\right.$ without tungsten), $3.5 \mathrm{~W}-\mathrm{V}$ (the best active catalyst), and $40 \mathrm{~W}-\mathrm{V}$ (excess tungsten) using operando IR and UV-Vis measurements. It was found that the vanadium site plays a role as a redox site and the tungsten site contributed to the acid sites for adsorption of ammonia. With an increase in tungsten, the activity decreased because the number of redox sites decreased for high tungsten coverage despite the increase in the number of acid sites. Acid sites of tungstensubstituted vanadium oxide were converted to Brønsted acid sites under a wet condition, while vanadium oxide without tungsten did not show a significant change in the population. From operando UV-Vis measurements, $3.5 \mathrm{~mol} \%$ tungsten-substituted vanadium oxide showed high redox capabilities even in the presence of water, and $\mathrm{N}_{2}$ production during the reduction half-cycle was hardly affected by the addition of water. The $3.5 \mathrm{~W}-\mathrm{V}$ catalyst had the high redox ability and reactivity of Brønsted acid sites at a low temperature in the presence of water. These results evidence water tolerance of bulk tungsten-substituted vanadium oxide. Although our results experimentally demonstrated the effect of water on the $\mathrm{NH}_{3}$-SCR cycle over the $\mathrm{V}-\mathrm{W}$ oxide system, the detailed reaction mechanism needs to be elucidated since water molecules may participate in each elementary reaction step. The acid and redox properties and the effect of water would also change depending on various factors such as the morphology, exposed facet, and surface reconstruction. We believe that our results provide a better understanding of $\mathrm{NH}_{3}-\mathrm{SCR}$ at a low temperature, which is a future task for the current deNOx process.

\section{Methods}

Reagents. $\mathrm{NH}_{4} \mathrm{VO}_{3}$ and oxalic acid were purchased from FUJIFILM Wako Pure Chemical Corporation. Ammonium metatungstate $\left(\left(\mathrm{NH}_{4}\right)_{6}\left[\mathrm{H}_{2} \mathrm{~W}_{12} \mathrm{O}_{40}\right] \cdot n \mathrm{H}_{2} \mathrm{O}\right.$, $n \fallingdotseq 6)$ was purchased from Nippon Inorganic Colour \& Chemical Co., Ltd. All reagents were used without further purification.

Synthesis of tungsten-substituted vanadium oxide catalysts. First, $\mathrm{NH}_{4} \mathrm{VO}_{3}$ and oxalic acid $(11.9 \mathrm{~g}, 131.7 \mathrm{mmol})$ were dissolved in $50 \mathrm{~mL}$ of water and the aqueous solution was stirred for $10 \mathrm{~min}$ for completion of the change in color of 


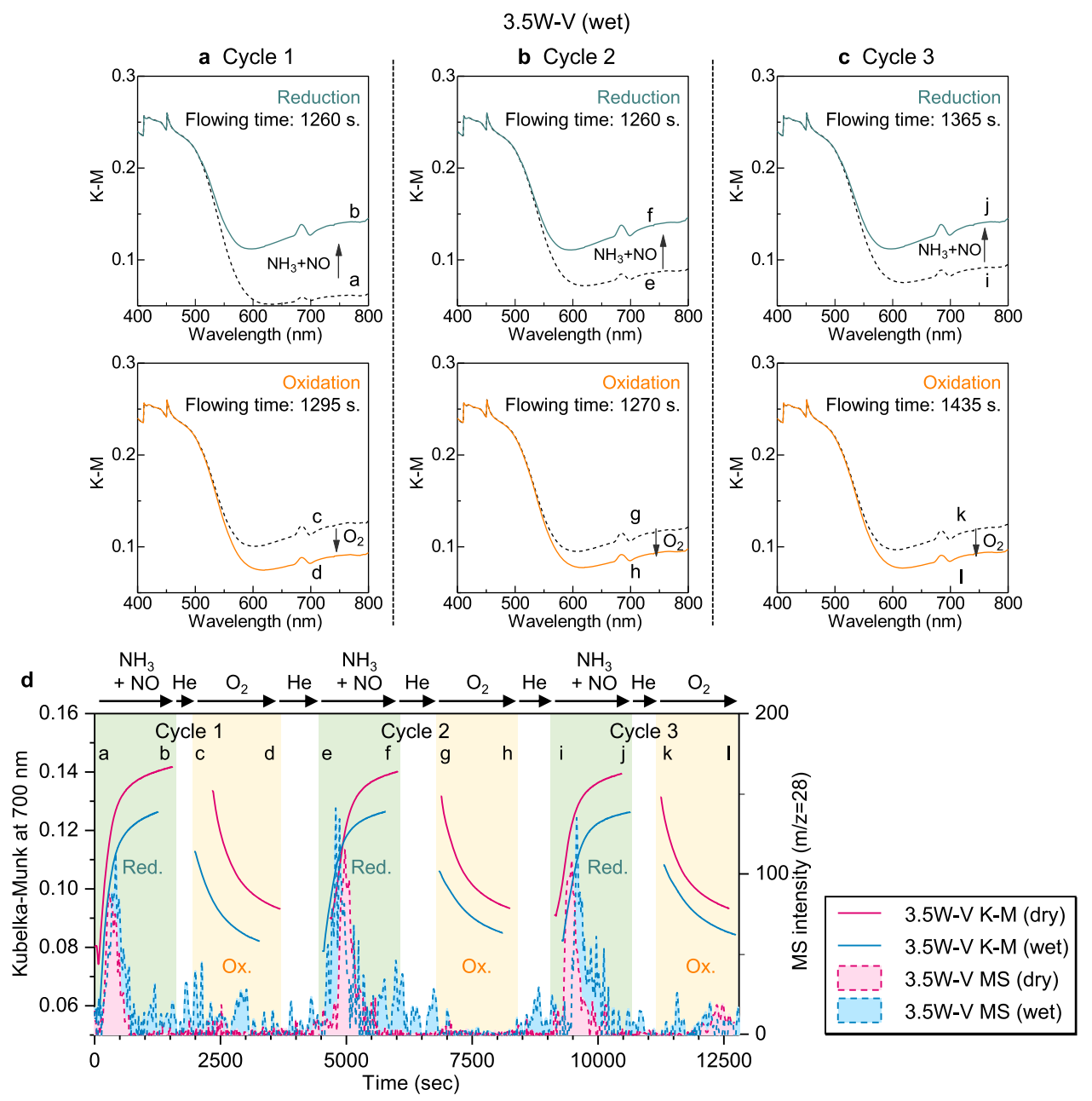

Fig. 9 Redox properties of $\mathbf{W}$-substituted vanadium oxide (3.5W-V) under wet and dry conditions. Operando UV-Vis spectra of $3.5 \mathrm{~W}-\mathrm{V}$ for reduction $\left(500 \mathrm{ppm} \mathrm{NO}+500 \mathrm{ppm} \mathrm{NH_{3 }}\right.$ ) and oxidation $\left(8 \% \mathrm{O}_{2}\right)$ half-cycles at $150^{\circ} \mathrm{C}$ under a wet $(2 \mathrm{vol} \%$ water) atmosphere for the a first cycle, $\mathbf{b}$ second cycle, and $\mathbf{c}$ third cycle. $\mathbf{d}$ Change in the Kubelka-Munk unit at $\lambda=700 \mathrm{~nm}$ and MS intensity of $\mathrm{N}_{2}$ as a function of time for $3.5 \mathrm{~W}-\mathrm{V}$ during NO (500 ppm) $+\mathrm{NH}_{3}$ $(500 \mathrm{ppm})$ and $\mathrm{O}_{2}(8 \%)$ flowing at $150^{\circ} \mathrm{C}$ under a dry atmosphere and wet (2 vol\% water) atmosphere. The characters a-l correspond to the points at which the UV-Vis spectra were observed.
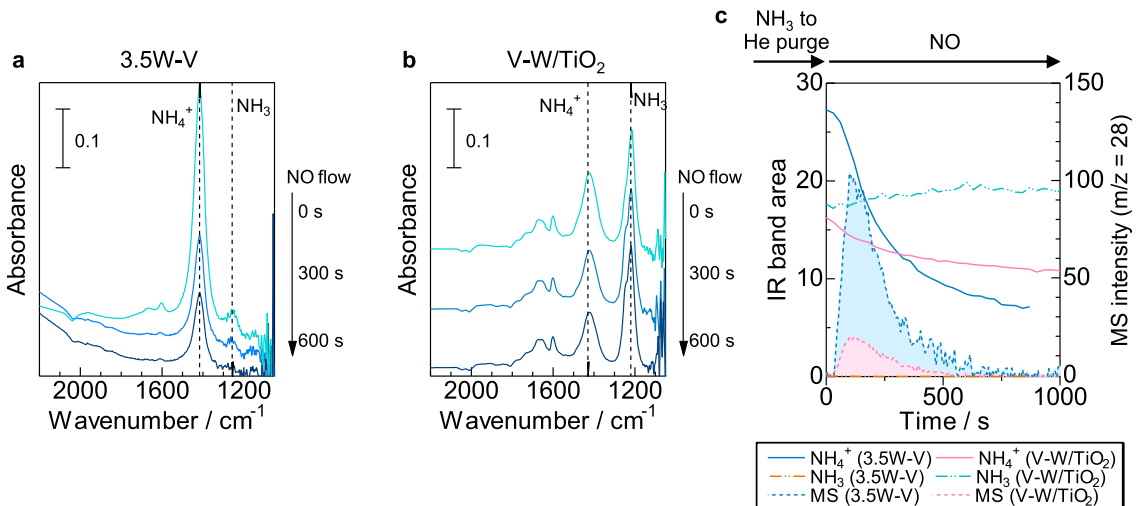

Fig. 10 Difference between bulk and supported catalysts. Operando IR spectra of ad species on a 3.5W-V (bulk W-substituted vanadium oxide) and b $\mathrm{V}-\mathrm{W} / \mathrm{TiO}_{2}$ (supported catalyst) during $\mathrm{NH}_{3}$ adsorption in the presence of water followed by $\mathrm{NO}$ exposure at $200^{\circ} \mathrm{C}$. The IR disc was exposed to $0.1 \%$ $\mathrm{NH}_{3} / \mathrm{He}$ flow in the presence of $2 \%$ water vapor $(30 \mathrm{~min})$ and purged with $\mathrm{He}(2 \mathrm{Omin})$, followed by exposure to $500 \mathrm{p} . \mathrm{pm} \mathrm{NO}(\mathrm{He}$ balance) flow. c IR peak areas of ammonia species adsorbed on Brønsted acid sites $\left(\mathrm{NH}_{4}{ }^{+}\right)$and $\mathrm{MS}$ intensity of $\mathrm{N}_{2}$ versus time of NO flowing.

the solution. Next, ammonium metatungstate was added to the solution. Then, the solution was heated overnight to evaporate the water on a hotplate. Finally, the resulting solid was calcined twice at $300^{\circ} \mathrm{C}$ for $4 \mathrm{~h}$ each time. The sample was denoted as $x \mathrm{~W}-\mathrm{V}$, where $x$ is the molar ratio $(\mathrm{mol} \%)$ of $\mathrm{W}$ to $\mathrm{V}$. The amounts of reagents are shown in Supplementary Table 1.

\section{Synthesis of $\mathrm{TiO}_{2}$-supported $\mathrm{V}_{2} \mathrm{O}_{5} / \mathrm{WO}_{3}\left(1 \mathrm{wt} \% \mathrm{~V}_{2} \mathrm{O}_{5}-5 \mathrm{wt} \% \mathrm{WO}_{3} / \mathrm{TiO}_{2}\right)$.}

First, vanadium and tungsten precursor aqueous solutions were prepared. For the vanadium precursor aqueous solution, $0.020 \mathrm{~g}$ of $\mathrm{NH}_{4} \mathrm{VO}_{3}(0.17 \mathrm{mmol})$ and $0.045 \mathrm{~g}$ of oxalic acid $(0.51 \mathrm{mmol})$ were dissolved in $2 \mathrm{~mL}$ of water and the aqueous solution was stirred for $10 \mathrm{~min}$. For the tungsten precursor aqueous solution, 0.084 
$\mathrm{g}$ of ammonium metatungstate hydrate $(0.028 \mathrm{mmol})$ and $0.089 \mathrm{~g}$ of oxalic acid $(0.99 \mathrm{mmol})$ were dissolved in $2 \mathrm{~mL}$ of water and the aqueous solution was stirred for $10 \mathrm{~min}$. Then. $1.4 \mathrm{~g}$ of $\mathrm{TiO}_{2}$ (P25) was added to $20 \mathrm{~mL}$ water and the vanadium and tungsten precursor aqueous solutions were added to the dispersion. The dispersion was then heated at $120^{\circ} \mathrm{C}$ to evaporate the water. Finally, the resulting solid was calcined at $300^{\circ} \mathrm{C}$ for $4 \mathrm{~h}$.

Catalyst characterization. STEM images were obtained by using FEI Titan Cubed G2 60-300. For TEM measurements, samples were deposited on a carbon filmcoated mesh copper grid. XRD patterns were collected by SmartLab (Rigaku) with $\mathrm{Cu} \mathrm{Ka}$ radiation. Rietveld analyses were carried out using Reflex program in Materials Studio 2017.

Catalytic activity test. The $\mathrm{NH}_{3}$-SCR activity of vanadium oxide catalysts was measured using a fixed-bed flow reactor (Supplementary Fig. 1). The reaction gas mixture, $250 \mathrm{ppm} \mathrm{NO}, 250 \mathrm{ppm} \mathrm{NH}_{3}, 4 \mathrm{vol} \% \mathrm{O}_{2}$ and 5-20 vol\% water (when used) in $\operatorname{Ar}\left(250 \mathrm{~mL} \mathrm{~min}^{-1}\right)$, was fed to the catalyst $(0.375 \mathrm{~g})$. The outlet gases were analyzed by an IR spectrometer (JASCO FT/IR-4700) equipped with a gas cell (JASCO LPC12M-S). NO conversion and $\mathrm{N}_{2}$ selectivity were calculated by the following equations:

$$
\begin{gathered}
\text { NO conversion }(\%)=\frac{\mathrm{NO}_{\text {in }}-\mathrm{NO}_{\text {out }}}{\mathrm{NO}_{\text {in }}} \times 100, \\
\mathrm{~N}_{2} \operatorname{selectivity}(\%) \frac{2 \times \mathrm{N}_{2 \text { out }}}{\left(\mathrm{NO}_{\text {in }}+\mathrm{NH}_{3 \text { in }}\right)-\left(\mathrm{NO}_{\text {out }}+\mathrm{NH}_{3 \text { out }}\right)} \\
\left(2 \times \mathrm{N}_{\text {out }}=\left(\mathrm{NO}_{\text {in }}+\mathrm{NH}_{3 \text { in }}\right)-\left(\mathrm{NO}_{\text {out }}+\mathrm{NH}_{3 \text { out }}+\mathrm{NO}_{2 \text { out }}+2 \times \mathrm{N}_{2} \mathrm{O}_{\text {out }}\right)\right) .
\end{gathered}
$$

Reaction rate and reaction order of the catalysts were determined by adjusting the amount of catalysts and the flow rate for NO conversion to be below $20 \%$.

Operando FT-IR measurements. Operando FT-IR spectra were recorded at $150^{\circ} \mathrm{C}$ using a JASCO FT/IR-4200 with a TGS (triglycine sulfate) detector. Samples (each $40 \mathrm{mg}$ ) were pressed to obtain self-supporting pellets $(\phi=20 \mathrm{~mm})$, which were placed in a quartz IR cell with $\mathrm{CaF}_{2}$ windows connected to a conventional gas flow system. Prior to measurements, the sample pellets were heated under a flow of $10 \%$ $\mathrm{O}_{2} / \mathrm{He}\left(100 \mathrm{~mL} \mathrm{~min}^{-1}\right)$ at $300{ }^{\circ} \mathrm{C}$ for $10 \mathrm{~min} . \mathrm{NH}_{3} / \mathrm{He}(0.1 \%)$ was then introduced for $0.5 \mathrm{~h}$, and subsequently, the gas was switched to $\mathrm{He}(20 \mathrm{~min})$ in order to let the residual $\mathrm{NH}_{3}$ gas out. After taking the first spectrum, $500 \mathrm{ppm} \mathrm{NO}, 8 \% \mathrm{O}_{2}$ (when used)/He was introduced to the sample at a flow rate of $100 \mathrm{~mL} \mathrm{~min}^{-1}$. For the measurement under a wet condition, $2 \% \mathrm{H}_{2} \mathrm{O}$ was introduced. Spectra were measured by accumulating 20 scans at a resolution of $4 \mathrm{~cm}^{-1}$. A reference spectrum taken at $150^{\circ} \mathrm{C}$ under $\mathrm{He}$ flow was subtracted from each spectrum. An MS (BELMass, MicrotracBEL Corp.) was used for the analysis of $\mathrm{N}_{2}$ gas.

Operando UV-Vis measurements. Diffuse reflectance UV-Vis measurements were conducted at $150^{\circ} \mathrm{C}$ with a UV-Vis spectrometer (JASCO V-670) connected to an operando flow cell with a quartz window. The light source was led to an integrating sphere through an optical fiber. Samples (each $10 \mathrm{mg}$ ) were placed in the sample cell connected to a gas flow system. Reflectance was converted to KM units using the KM function. A background spectrum was corrected by measuring $\mathrm{BaSO}_{4}$. Prior to measurements, the sample pellets were heated under a flow of $10 \%$ $\mathrm{O}_{2} / \mathrm{He}\left(100 \mathrm{~mL} \mathrm{~min}^{-1}\right)$ at $300^{\circ} \mathrm{C}$ for $10 \mathrm{~min}$. Then, the sample pellets were cooled down to $150^{\circ} \mathrm{C}$. The measurements were performed by the following steps: (i) The sample pellets were purged with He flow to remove residual oxygen and the initial UV-Vis spectra were measured (spectra 1). (ii) A gas mixture (500 $\mathrm{ppm} \mathrm{NH}_{3}+$ $500 \mathrm{ppm} \mathrm{NO} / \mathrm{He}$ ) was fed to a sample at a flow rate of $100 \mathrm{~mL} \mathrm{~min}^{-1}$ for a given time. Then, UV-vis spectra were recorded (spectra 2). (iii) After turning off the gas flow, the sample pellets were purged with He flow followed by UV-Vis spectra acquisition (spectra 3). (iv) Then, a gas mixture $\left(8 \% \mathrm{O}_{2} / \mathrm{He}\right)$ was fed to a sample at a flow rate of $100 \mathrm{~mL} \mathrm{~min}^{-1}$ for a given time and UV-Vis spectra were obtained (spectra 4). Steps (i)-(iv) were regarded as one cycle. The change in the KM unit at $\lambda=700 \mathrm{~nm}\left(\Delta \mathrm{KM}_{700}\right)$, which was assigned to the $d-d$ transition of $\mathrm{V}^{4+}$, was measured to obtain the relative amount of redox sites. $\Delta \mathrm{KM}_{700}$ values for reduction $\left(\mathrm{V}^{5+}\right.$ reduced by $\left.\mathrm{NO}+\mathrm{NH}_{3}\right)$ and oxidation $\left(\mathrm{V}^{4+}\right.$ oxidized by $\left.\mathrm{O}_{2}\right)$ half-cycles were calculated by the following equations:

$\left(\Delta \mathrm{KM}_{700}\right.$ for reduction half cycle $)=\left(\mathrm{KM}_{700}\right.$ in spectra 2$)-\left(\mathrm{KM}_{700}\right.$ in spectra 1$)$,

$\left(\Delta \mathrm{KM}_{700}\right.$ for oxidation half cycle $)=\left(\mathrm{KM}_{700}\right.$ in spectra 4$)-\left(\mathrm{KM}_{700}\right.$ in spectra 3$)$.

The production of $\mathrm{N}_{2}$ in the outlet gas mixture was monitored by an MS (BELMass, MicrotracBEL Corp.).

Others. The crystal structure was drawn by VESTA ${ }^{59}$

\section{Data availability}

The data that support the findings of this study are available from the corresponding author upon reasonable request.

Received: 17 August 2020; Accepted: 14 December 2020; Published online: 25 January 2021

\section{References}

1. Han, L. et al. Selective catalytic reduction of $\mathrm{NOx}$ with $\mathrm{NH}_{3}$ by using novel catalysts: state of the art and future prospects. Chem. Rev. 119, 10916-10976 (2019).

2. Lai, J. \& Wachs, I. E. A perspective on the selective catalytic reduction (SCR) of $\mathrm{NO}$ with $\mathrm{NH}_{3}$ by supported $\mathrm{V}_{2} \mathrm{O}_{5}-\mathrm{WO}_{3} / \mathrm{TiO}_{2}$ catalysts. ACS Catal. 8, 6537-6551 (2018).

3. Marberger, A., Elsener, M., Ferri, D. \& Kröcher, O. VOx surface coverage optimization of $\mathrm{V}_{2} \mathrm{O}_{5} / \mathrm{WO}_{3}-\mathrm{TiO}_{2}$ SCR catalysts by variation of the $\mathrm{V}$ loading and by aging. Catalysts 5, 1704-1720 (2015).

4. Nakajima, F. \& Hamada, I. The state-of-the-art technology of NOx control. Catal. Today 29, 109-115 (1996).

5. Boningari, T. \& Smirniotis, P. G. Impact of nitrogen oxides on the environment and human health: Mn-based materials for the NOx abatement Curr. Opin. Chem. Eng. 13, 133-141 (2016).

6. Peng, Y., Chang, H., Dai, Y. \& Li, J. Structural and Surface Effect of $\mathrm{MnO}_{2}$ for Low Temperature Selective Catalytic Reduction of $\mathrm{NO}$ with $\mathrm{NH}_{3}$. Procedia Environ. Sci. 18, 384-390 (2013).

7. Smirniotis, P. G., Peña, D. A. \& Uphade, B. S. Low-Temperature Selective Catalytic Reduction (SCR) of NO with $\mathrm{NH}_{3}$ by Using $\mathrm{Mn}, \mathrm{Cr}$, and $\mathrm{Cu}$ Oxides Supported on Hombikat $\mathrm{TiO}_{2}$. Angew. Chem. Int. Ed. 40, 2479-2482 (2001).

8. $\mathrm{Xu}, \mathrm{H}$. et al. Design and synthesis of highly-dispersed $\mathrm{WO}_{3}$ catalyst with highly effective $\mathrm{NH}_{3}$-SCR activity for NOx abatement. ACS Catal. 9, 11557-11562 (2019)

9. Gillot, S. et al. Development of stable and efficient $\mathrm{CeVO}_{4}$ systems for the selective reduction of NOx by ammonia: structure-activity relationship. Appl. Catal. B 218, 338-348 (2017).

10. Huang, L. et al. Hydrothermal growth and characterization of length tunable porous iron vanadate one-dimensional nanostructures. CrystEngComm 16, 5128-5133 (2014).

11. Nakasaka, Y. et al. Micropore diffusivities of $\mathrm{NO}$ and $\mathrm{NH}_{3}$ in $\mathrm{Cu}-\mathrm{ZSM}-5$ and their effect on $\mathrm{NH}_{3}$-SCR. Catal. Today 332, 64-68 (2019).

12. Sullivan, J. A. \& Keane, O. The role of Bronstead acidity in poisoning the SCR urea reaction over FeZSM-5 catalysts. Appl. Catal. B 61, 244-252 (2005).

13. Kieffer, C., Lavy, J., Jeudy, E., Bats, N. \& Delahay, G. Characterisation of a commercial automotive $\mathrm{NH}_{3}$-SCR copper-zeolite catalyst. Top. Catal. 56, 40-44 (2013).

14. De-La-Torre, U., Pereda-Ayo, B., Moliner, M., González-Velasco, J. R. \& Corma, A. Cu-zeolite catalysts for $\mathrm{NO}_{\mathrm{x}}$ removal by selective catalytic reduction with $\mathrm{NH}_{3}$ and coupled to $\mathrm{NO}$ storage/reduction monolith in diesel engine exhaust aftertreatment systems. Appl. Catal. B 187, 419-427 (2016).

15. Fahami, A. R. et al. The dynamic nature of $\mathrm{Cu}$ sites in $\mathrm{Cu}-\mathrm{SSZ}-13$ and the origin of the seagull $\mathrm{NO}_{\mathrm{x}}$ conversion profile during $\mathrm{NH}_{3}$-SCR. React. Chem. Eng. 4, 1000-1018 (2019).

16. Song, J. et al. Toward rational design of $\mathrm{Cu} / \mathrm{SSZ}-13$ selective catalytic reduction catalysts: implications from atomic-level understanding of hydrothermal stability. ACS Catal. 7, 8214-8227 (2017).

17. Kwak, J. H., Tonkyn, R. G., Kim, D. H., Szanyi, J. \& Peden, C. H. F. Excellent activity and selectivity of Cu-SSZ-13 in the selective catalytic reduction of $\mathrm{NO}$ with $\mathrm{NH}_{3}$. J. Catal. 275, 187-190 (2010).

18. Inomata, $\mathrm{Y}$. et al. Bulk vanadium oxide versus conventional $\mathrm{V}_{2} \mathrm{O}_{5} / \mathrm{TiO}_{2}: \mathrm{NH}_{3}$ SCR catalysts working at a low temperature below $150{ }^{\circ} \mathrm{C}$. ACS Catal. 9, 9327-9331 (2019).

19. Inomata, Y. et al. Synthesis of bulk vanadium oxide with a large surface area using organic acids and its low-temperature $\mathrm{NH}_{3}$-SCR activity. Catal. Today https://doi.org/10.1016/j.cattod.2020.06.041 (2020).

20. He, G. et al. Polymeric vanadyl species determine the low-temperature activity of V-based catalysts for the SCR of $\mathrm{NO}_{x}$ with $\mathrm{NH}_{3}$. Sci. Adv. 4, eaau4637 (2018).

21. Qu, W. et al. Single-atom catalysts reveal the dinuclear characteristic of active sites in NO selective reduction with $\mathrm{NH}_{3}$. Nat. Commun. 11, 1-7 (2020).

22. Ganjkhanlou, Y. et al. Location and activity of $\mathrm{VOx}$ species on $\mathrm{TiO}_{2}$ particles for $\mathrm{NH}_{3}$-SCR catalysis. Appl. Catal. B 278, 119337 (2020).

23. Wachs, I. E. Catalysis science of supported vanadium oxide catalysts. Dalton Trans. 42, 11762-11769 (2013).

24. Kristoffersen, H. H. \& Metiu, H. Reconstruction of low-index a$\mathrm{V}_{2} \mathrm{O}_{5}$ surfaces. J. Phys. Chem. C 119, 10500-10506 (2015). 
25. Wachs, I. E. The generality of surface vanadium oxide phases in mixed oxide catalysts. Appl. Catal. A 391, 36-42 (2011).

26. Wang, Q. et al. Research progress on vanadium-based cathode materials for sodium ion batteries. J. Mater. Chem. A 6, 8815-8838 (2018).

27. Bahlawane, N. \& Lenoble, D. Vanadium oxide compounds: structure, properties, and growth from the gas phase. Chem. Vap. Depos. 20, 299-311 (2014).

28. Weckhuysen, B. M. \& Keller, D. E. Chemistry, spectroscopy and the role of supported vanadium oxides in heterogeneous catalysis. Catal. Today $\mathbf{7 8 ,}$ 25-46 (2003).

29. Wang, Y., Takahashi, K., Shang, H. \& Cao, G. Synthesis and electrochemical properties of vanadium pentoxide nanotube arrays. J. Phys. Chem. B 109, 3085-3088 (2005).

30. Wei, Y., Ryu, C. W. \& Kim, K. B. Cu-doped $\mathrm{V}_{2} \mathrm{O}_{5}$ as a high-energy density cathode material for rechargeable lithium batteries. J. Alloy. Compd. 459, L13-L17 (2008).

31. Grégoire, G., Baffier, N., Kahn-Harari, A. \& Badot, J. C. X-ray powder diffraction study of a new vanadium oxide $\mathrm{Cr}_{0.11} \mathrm{~V}_{2} \mathrm{O}_{5.16}$ synthesized by a solgel process. J. Mater. Chem. 8, 2103-2108 (1998).

32. Jovanović, A. et al. Structural and electronic properties of $\mathrm{V}_{2} \mathrm{O}_{5}$ and their tuning by doping with $3 \mathrm{~d}$ elements-modelling using the DFT $+\mathrm{U}$ method and dispersion correction. Phys. Chem. Chem. Phys. 20, 13934-13943 (2018).

33. Kaper, $\mathrm{H}$. et al. Ionic liquid- and surfactant-controlled crystallization of $\mathrm{WO}_{3}$ films. Phys. Chem. Chem. Phys. 17, 18138-18145 (2015).

34. Mardare, C. C. \& Hassel, A. W. Review on the versatility of tungsten oxide coatings. Phys. Stat. Sol. 216, 1900047 (2019).

35. Wang, S., Fan, W., Liu, Z., Yu, A. \& Jiang, X. Advances on tungsten oxide based photochromic materials: strategies to improve their photochromic properties. J. Mater. Chem. C 6, 191-212 (2018).

36. Jaegers, N. R. et al. Mechanism by which tungsten oxide promotes the activity of supported $\mathrm{V}_{2} \mathrm{O}_{5} / \mathrm{TiO}_{2}$ catalysts for $\mathrm{NO}_{\mathrm{X}}$ abatement: structural effects revealed by ${ }^{51}$ V MAS NMR spectroscopy. Angew. Chem. Int. Ed. 58, 12609-12616 (2019).

37. Lintz, H. G. \& Turek, T. Intrinsic kinetics of nitric oxide reduction by ammonia on a vanadia-titania catalyst. Appl. Catal. A 85, 13-25 (1992).

38. Dumesic, J. A., Topsøe, N. Y., Topsøe, H., Chen, Y. \& Slabiak, T. Kinetics of selective catalytic reduction of nitric oxide by ammonia over vanadia/titania. $J$. Catal. 163, 409-417 (1996).

39. Lietti, L., Nova, I. \& Forzatti, P. Selective catalytic reduction (SCR) of NO by $\mathrm{NH}_{3}$ over $\mathrm{TiO}_{2}$-supported $\mathrm{V}_{2} \mathrm{O}_{5}-\mathrm{WO}_{3}, \mathrm{~V}_{2} \mathrm{O}_{5}-\mathrm{MoO}_{3}$ catalysts. Top. Catal. 11-12, 111-122 (2000)

40. Turco, M., Lisi, L., Pirone, R. \& Ciambelli, P. Effect of water on the kinetics of nitric oxide reduction over a high-surface-area $\mathrm{V}_{2} \mathrm{O}_{5} / \mathrm{TiO}_{2}$ catalyst. Appl. Catal. B 3, 133-149 (1994).

41. Tufano, V. \& Turco, M. Kinetic modelling of nitric oxide reduction over a high-surface area $\mathrm{V}_{2} \mathrm{O}_{5}-\mathrm{TiO}_{2}$ catalyst. Appl. Catal. B 2, 9-26 (1993).

42. Long, R. Q. \& Yang, R. T. Selective catalytic reduction of NO with ammonia over $\mathrm{V}_{2} \mathrm{O}_{5}$ doped $\mathrm{TiO}_{2}$ pillared clay catalysts. Appl. Catal. B 24, 13-21 (2000).

43. Forzatti, P. Present status and perspectives in de-NOx SCR catalysis. Appl. Catal. A 222, 221-236 (2001).

44. Forzatti, P. Environmental catalysis for stationary applications. Catal. Today 62, 51-65 (2000)

45. Topsøe, N.-Y., Slabiak, T., Clausen, B. S., Srnak, T. Z. \& Dumesic, J. A. Influence of water on the reactivity of vanadia/titania for catalytic reduction of NOx. J. Catal. 134, 742-746 (1992).

46. Nova, I., Lietti, L., Tronconi, E. \& Forzatti, P. Transient responce method applied to the kinetic analysis of the DeNOx-SCR reaction. Chem. Eng. Sci. 56, 1229-1237 (2001).

47. Yin, X. et al. Adsorption of $\mathrm{H}_{2} \mathrm{O}$ on the $\mathrm{V}_{2} \mathrm{O}_{5}(010)$ surface studied by periodic density functional calculations. J. Phys. Chem. B 103, 3218-3224 (2002).

48. Broclawik, E., Góra, A. \& Najbar, M. The role of tungsten in formation of active sites for no SCR on the V-W-O catalyst surface-quantum chemical modeling (DFT). J. Mol. Catal. A 166, 31-38 (2001).

49. Da Costa, A. et al. Observation of the $\mathrm{V}_{2} \mathrm{O}_{5}(001)$ surface using ambient atomic force microscopy. Surf. Sci. 370, 339-344 (1997).

50. Inomata, M., Miyamoto, A. \& Murakami, Y. Mechanism of the reaction of NO and $\mathrm{NH}_{3}$ on vanadium oxide catalyst in the presence of oxygen under the dilute gas condition. J. Catal. 62, 140-148 (1980).

51. Zhu, M., Lai, J.-K., Tumuluri, U., Wu, Z. \& Wachs, I. E. Nature of active sites and surface intermediates during SCR of NO with $\mathrm{NH}_{3}$ by supported $\mathrm{V}_{2} \mathrm{O}_{5}-\mathrm{WO}_{3} / \mathrm{TiO}_{2}$ catalysts. J. Am. Chem. Soc. 139, 15624-15627 (2017).

52. Marberger, A., Ferri, D., Elsener, M. \& Kröcher, O. The significance of Lewis acid sites for the selective catalytic reduction of nitric oxide on vanadiumbased catalysts. Angew. Chem. 55, 11989-11994 (2016).
53. Topsøe, N. Y., Dumesic, J. A. \& Topsøe, H. Vanadia-titania catalysts for selective catalytic reduction of nitric-oxide by ammonia. II. Studies of active sites and formulation of catalytic cycles. J. Catal. 151, 241-252 (1995).

54. Topsøe, N. Y., Topsøe, H. \& Dumesic, J. A. Vanadia/titania catalysts for selective catalytic reduction (SCR) of nitric-oxide by ammonia. I. Combined temperature-programmed in-situ ftir and on-line mass-spectroscopy studies. J. Catal. 151, 226-240 (1995).

55. Song, I., Lee, H., Jeon, S. W. \& Kim, D. H. Understanding the dynamic behavior of acid sites on $\mathrm{TiO}_{2}$-supported vanadia catalysts via operando DRIFTS under SCR-relevant conditions. J. Catal. 382, 269-279 (2020)

56. Satsuma, A. et al. Surface active sites of vanadium pentoxide-tungsten trioxide catalysts. J. Phys. Chem. 92, 6052-6058 (1988).

57. Busca, G., Lietti, L., Ramis, G. \& Berti, F. Chemical and mechanistic aspects of the selective catalytic reduction of $\mathrm{NO}(\mathrm{x})$ by ammonia over oxide catalysts: a review. Appl. Catal. B 18, 1-36 (1998).

58. Kung, H. H. Transition Metal Oxides: Surface Chemistry and Catalysis (Elsevier, 1989).

59. Momma, K. \& Izumi, F. VESTA 3 for three-dimensional visualization of crystal, volumetric and morphology data. J. Appl. Crystallogr. 44, 1272-1276 (2011).

\section{Acknowledgements}

This work was supported, in part, by the Cooperative Research Program of Institute for Catalysis, Hokkaido University (20B1021), Nanotechnology Platform Program of the Ministry of Education, Culture, Sports, Science and Technology (MEXT), Japan and JSPS KAKENHI (20K15092).

\section{Author contributions}

Y.I. and T.M. conceived the original concept and designed the experiments. Y.I. conducted the experiments and wrote the manuscript. H.K. carried out the operando UV measurements and helped Y.I. to measure operando IR spectra. T.T. and K.-i.S. supervised the operando measurements and supported the analysis of the results. S.I. and W.U. conducted the Rietveld analysis. S.H. helped synthesis catalysts. N.S. carried out HAADFSTEM measurements. E.K., K.M., and K.Y. supported catalytic activity test. M.H. gave advice about the interpretation of the results. T.M. supervised this project. All authors contributed to discuss the results.

\section{Competing interests}

The authors declare no competing interests.

\section{Additional information}

Supplementary information is available for this paper at https://doi.org/10.1038/s41467 020-20867-w.

Correspondence and requests for materials should be addressed to T.M.

Peer review information Nature Communications thanks Gloria Berlier, JianZhi Hu and Hong He for their contribution to the peer review of this work. Peer reviewer reports are available.

Reprints and permission information is available at http://www.nature.com/reprints

Publisher's note Springer Nature remains neutral with regard to jurisdictional claims in published maps and institutional affiliations.

Open Access This article is licensed under a Creative Commons Attribution 4.0 International License, which permits use, sharing, adaptation, distribution and reproduction in any medium or format, as long as you give appropriate credit to the original author(s) and the source, provide a link to the Creative Commons license, and indicate if changes were made. The images or other third party material in this article are included in the article's Creative Commons license, unless indicated otherwise in a credit line to the material. If material is not included in the article's Creative Commons license and your intended use is not permitted by statutory regulation or exceeds the permitted use, you will need to obtain permission directly from the copyright holder. To view a copy of this license, visit http://creativecommons.org/ licenses/by/4.0/

(C) The Author(s) 2021 